\title{
Where Are the Ugandan Youth? Socio-Economic Characteristics and Implications for Youth Employment in Uganda
}

\author{
Edward Bbaale ${ }^{1}$ \\ ${ }^{1}$ Center for Basic Research and School of Economics, Makerere University, Kampala, Uganda \\ Correspondence: Edward Bbaale, Center for Basic Research and School of Economics, Makerere University, \\ Kampala, Uganda. E-mail: edward_bbaale@yahoo.com; ebbaale@fema.mak.ac.ug
}

Received: September 9, 2013 Accepted: October 18, 2013 Online Published: February 28, 2014

doi:10.5539/jpl.v7n1p37～URL: http://dx.doi.org/10.5539/jpl.v7n1p37

\begin{abstract}
This paper undertook a structural analysis of the youth labor force in Uganda by documenting their location in the Ugandan economy by residence, region, sector, and employment status. The data were obtained from the Uganda National Household Surveys 2002/03, 2005/06 and 2009/10. We find that the youth population structure of the country poses a big challenge in an effort to create employment, particular for the youth. The majority of the youth labor force is located in the rural compared to the urban areas of the country. Whereas we find quite impressive labor force participation rates and the employment population ratio, they do not necessarily reflect more and better employment opportunities because of the high degree of informality where most of the youth are underemployed. Over $90 \%$ of the youth were employed in the informal sector outside agriculture with slightly more female youth than their male counterparts. The quality of the youth labor in terms of education is improving though will lower attainment rates at postsecondary level, however, the quality of the youth labor force is higher in urban than in rural areas. An increase in self-employment is observed which is an indication of high rate of job creation is in the informal economy. Consequently, there is a limited participation of the youth in professional and technical occupations and in paid employment. By gender, it's surprising to observe that there more female youth employed as professionals compared to their male counterparts. However, it is noteworthy that the percentage of both male and female youth employed as professionals is on average less than $1 \%$. Connected to this is the finding that there is a higher proportion of the youth labor force employed in agriculture despite its dismal contribution to GDP. Whereas the country experienced sectoral shifts in GDP composition, with the services and manufacturing sector becoming more important than agriculture, there are no sectoral shifts in employment with agriculture remaining the main employer of the youth labor force. Very low youth unemployment rates are observed suggesting a significant time underemployment. Additionally, there is a significant proportion of the youth that are skill underemployed; their educational attainment was higher than the educational level required by their current main jobs. Youth unemployment problem is more of an urban phenomenon with a higher proportion of the youth unemployed in Kampala compared to other regions. Our findings suggest that increasing labor productivity in agricultural as well as in the non-agricultural informal sector where the majority of the youth are located might help to solve the youth unemployment and underemployment predicaments. There is also need to ensure access to cheap finance by the youth, practical education, secure premises for informal businesses, and design policies to slow down the current population growth rates.
\end{abstract}

\section{Introduction}

Globally, the population of the youth has grown exponentially especially in the South for the last two decades or so. As a result, the number of unemployed youth has rapidly risen. According to ILO (2012), the number unemployed youth is 73.4 million as of 2013. It is also documented that the global youth unemployment rate has been rising since 2011; it is currently estimated at 12.6 percent and is projected to increase to 12.8 percent by 2018. On the other hand, the global adult unemployment rate, while also rising slightly, is much lower at 4.6 percent in 2013 (Assaad et al., 2013). It's noteworthy that the nature and extent of employment of the youth is an important indicator of the additional employment generating capacity of the economy. Youth unemployment, on the other hand, signifies a jobless growth profile of an economy for new comers in the labor market and, by extension, loss of potential income and welfare (African Economic Outlook, 2012). The population characteristics currently prevailing in Uganda represent a significant threat rather than an opportunity to create 
employment for the citizens, most especially the youth. Uganda's current population is estimated at about 34.1 million (UBOS, Statistical Abstract, 2012). According to the Uganda Demographic and Health Survey (UDHS) final Report (2011), on average, a Ugandan woman would have 6.2 children by the end of her reproductive years, if the current fertility pattern were to prevail, a slight decline from 6.7 children per woman in 2006 (Uganda Bureau of Statistics and ICF International, 2011). This total fertility rate is associated with a population growth rate of $3.2 \%$ which is one of the highest in the world meaning that the country is only at the beginning of demographic transition. The young and rapidly growing population in Uganda implies that the labor market is flooded every year with new job seekers, especially in the cities, because this is where most wage and salary jobs, especially high paying jobs are found (Fox \& Gaal, 2008). The high population growth rate also means a high proportion of young people cannot find gainful employment especially in the rural areas. Many youths are engaged in small income-generating activities like boda boda, brick making, petty trade and in the service sector. Statistics from the Ministry of Gender, Labour and Social Development indicate that around 400,000 youth are annually released into the job market to compete for the mere 9,000 jobs available. The UDHS Report found that the total fertility rate in urban areas is much lower than that in the rural areas (3.8 and 6.8 children, respectively). However, rural-urban migration, especially amongst the teenagers, implies high urban unemployment despite the low urban fertility rate.

By way of definition, youth labor has been variously defined in Uganda. According to ILO definition, which is also the internationally accepted definition, adopted in the present study, the youth labour force refers to individuals in the 15-24 years of age. However, the constitution of Uganda considers all people in the age group 18-30 years as belonging to the youth population (African Economic Outlook, 2012). In this paper, we adopted the international definition (15-24 years) but we do comparisons with the national definition (18-30 years) and also with the population of the working age (14-64 years). The main objective of this paper was to undertake a structural mapping of the location of the youth in the economy; by residence, region, sector and employment status among other features. We used a descriptive approach where we mainly employed cross-tabulations in order to understand key associations in the youth labor market in Uganda.

\section{Methodology and Data}

The methodology entailed a comprehensive review of the various documents and reports that relate to employment and labor policy in Uganda. Where data permitted we undertook to compute some measurable indicators such as labor force, labor force participation rate, employment population ratio, and unemployment and underemployment rates. We then assessed how these are distributed across age cohorts, regions and locations, gender, sectors, and education attainment of the labor force. Other indicators of interest included the trend in overall GDP and the sectoral shares as well as their underpinnings and implications for employment. In instances where performance still lagged behind the expectation, we pointed out the specific constraints and the way forward. We also undertook to document trends in youth employment indicators in Uganda, within the salient features of the core policy frameworks that set a milestone for development, especially the MDG-consistent National Development Plan (NDP) 2010-2015. The thrust of this approach was to assess the performance of government policy against parameters and indicators such as growth of output, job creation, social sector outcomes, and poverty reduction. This provided the basis for discussing future prospects and the way forward.

The main sources of information included the various issues of the statistical abstract from the Uganda Bureau of Statistics, the annual budgets and the background to the budget. These provided information on economic indicators such as overall GDP growth rates and the sectoral shares. Information on the temporal and spatial dimensions of employment was obtained from the various rounds of the nationally representative Uganda National Household Surveys (UNHS) from the Uganda Bureau of Statistics; 2002/03, 2005/06, 2009/10. Household survey data provided information on the characteristics of the employed, informal sector employment and unemployed persons. In addition, the UNHS data aided the analysis by occupation, enterprise type, and status of employment (self-employment versus paid employment) as well as by location, age and gender.

\section{Results}

\subsection{Youth Population, Labor Force and Labor Force Participation Rates}

The youth population (15-24 years) has significantly increased by over 1 million youths between 2002 and 2010 . Quantitatively, the youth in the 15-24 years bracket increased from 4.5 million to 5 million and to $5.5 \mathrm{~m}$ in 2002, 2005, and 2010, respectively (Table 1). Similarly, the population of the old youths (25-35 years) also increased in the same period from 3.70 million to 3.73 million and to 4.3 million in 2002, 2005 and 2010, respectively. By national definition (18-30 years), the population of the youth increased from 5.5 million in 2002/2005 to 6.4 
million youths in 2009/10. There are also gender differences in the numbers of the youth in the various age brackets. In the entire period under study (2002-2010) and also for the different age brackets, the female youths outweigh the male youths (Table 1). The population of the female youth (15-24) in 2002 was 2.4 million compared to 2.1 million of their male counterparts again compared to 2.7 million female youth and 2.4 million male youth in 2005/06. In 2009/10, the population of the female youth (15-24 years) increased to 3 million which is still higher than their male counterparts who increased to 2.6 million (Table 1). Similarly, by the national definition (18-30 years), female youths outweigh the male youth. In 2002 there were 3.1 million female youth compared to 2.4 million male youth, 3.0 million female youth compared to 2.5 million youth in 2005 and 3.6 million female youth compared to 2.8 million male youth in 2010. There are more youth (15-24 years) in the rural compared to urban areas. There were .83 million youth in urban areas compared to 3.7 million youth in the rural areas as of 2003, .94 million youth in urban areas compared to 4 million youth in rural areas as of 2005 and 1.1 million youth urban areas compared to 4.5 million youth in rural areas. The same picture can be observed for other age cohorts 18-30 years and 25-35 years. By regional distribution by 2002/03; there were more youth (across all age cohorts) in the Eastern region followed by the Western, Central, Northern and Kampala coming last. In 2005/06, the youth were located more in the Western region compared to other regions. Yet, in 2009/10, the youth were located more in the Eastern region compared to other regions of Uganda. This is in line with the previous finding that the youth are located more in the rural than urban areas for the case of Uganda (Table 1). Thus, any efforts of the government and other development partners that can be intended to uplift the wellbeing of the youth should have its roots in the rural areas if they are to be comprehensive and inclusive of all the youth.

Labour force refers to economically active population aged 14-64 years, who were either employed or unemployed during the last seven days prior to the survey (UNHS Report 2005/06 and 2009/10). The unemployed referred to must be actively seeking and available for work. The labour force does not include persons engaged in non-economic activities including domestic chores such as cooking at home or caring for own children, as those activities do not contribute to measured national income according to the System of National Accounts (SNA) (UNHS Report, 2009/10). Since this study is concerned with youth employment, we considered only those individuals in labour force falling within the age bracket of the youth; 15-24 (international definition) and others like 25-35 (old youths) and 18-30 (national definition of the youth) in order to enrich comparability. Table 2 shows the distribution of the labour force by the aforementioned age cohorts of the youth, region and residence. Quantitatively, the youth labor force (15-24 years) has consistently increased from 2.9 million in 2002/03 to 3.5 million in 2005/06 and to 5.3 million in 2009/10. This represents a growth rate of $21 \%$ between 2002/03 and 2005/06 and 51\% between 2005/06 and 2009/10. These growth rates are quite high and represent a great challenge to the country to create opportunities for the youth at a pace that matches the growth rate in the youth labor force. By gender, for those in the 15-24 age cohort, there were more female youth in the labor force in 2002/03 (1.6 million female youth compared to 1.3 million male youth). This picture in consistent for the period 2005/06 (1.9 million female youth compared to 1.7 million male youth) and 2009/10 (2.9 million female youth compared to 2.4 million male youth). For old youth in the age cohort 25-35 years, there were 1.8 million female youth compared 1.7 million male youth, 1.72 million female youth compared to 1.68 million male youth and 2.2 million female youth compared to 2.1 million male youth for 2002/03, 2005/06, and 2009/10, respectively. The same picture can observed for the youth by national definition (18-30 years) where the female youth consistently outnumber the male youth (Table 2). Just as in the previous analysis of the population of the youth, there is more youth labor force in the rural than in the urban areas of Uganda. In 2002/03 there were 2.5 million youth labor force (15-24 years) in the rural areas compared to 0.45 million youth labor force in the urban areas. This number increased in 2005/06 with 3.1 million youth labor force in the rural areas compared to 0.47 million youth labor force in the urban areas. In 2009/10, the number of the youth increased exponentially with 4.2 million youth in the rural area compared to 1.2 million youth in the urban areas (Table 2).

In terms of the growth rate, between 2002 and 2005 the growth rate of the youth labor force was $24 \%$ in the rural compared to only 4\% in the urban area. Between 2005 and 2010, the growth rate of the youth labor force was 36\% in the rural compared to $155 \%$ in the urban area. The high growth rate of the youth labor force in the urban areas can be attributed to the big number of youth that graduate from Universities and other tertiary institutions and flood the labor market in cities in search for wage and salary jobs. These growth rates of the labor force are quite high representing a serious challenge to the government and other development partners in their efforts to alleviate youth unemployment. The same picture can be observed for other definitions of the youth considered in this study. Rural areas cannot be left behind while designing any efforts intended to create labor market opportunities for the youth as they house the majority of the youth in the country. In terms of regional distribution, as of 2002/03 there were more youth in the labor force in the Eastern region, followed by the Central region, Western region, Northern region and Kampala comes last. In 2005/06, there were more youth in 
the labor force in the Western region followed by the Eastern region, Central region, Northern region, and Kampala comes last. In 2009/10, there were more youth in the labour force in the Eastern region followed by the Western region, Central region, Northern region and Kampala comes last. It's noteworthy that there was a drastic increase in the number of the youth in the labour force in all regions of the country. The same picture can be observed for other definitions of the youth (Table 2).

Table 1. Total population of the working age by sex, age cohorts, region and residence (Millions)

\begin{tabular}{|c|c|c|c|c|c|c|c|c|c|c|}
\hline & \multicolumn{3}{|c|}{ UNHS 2002/03 } & \multicolumn{4}{|c|}{ UNHS 2005/06 } & \multicolumn{3}{|c|}{ UNHS 2009/10 } \\
\hline & $15-24$ & 25-35 & $18-30$ & $15-24$ & 25-35 & $18-30$ & $14-64$ & $15-24$ & $25-35$ & $18-30$ \\
\hline Male & $2,088,409$ & 1,718,393 & $2,371,105$ & 2,387,926 & $1,776,738$ & $2,494,877$ & $6,887,492$ & $2,568,931$ & $2,044,817$ & 2,819,558 \\
\hline Female & $2,429,787$ & $1,982,730$ & $3,126,085$ & 2,645,362 & $1,952,496$ & $3,007,626$ & $7,711,166$ & $3,002,663$ & $2,225,304$ & $3,556,031$ \\
\hline Urban & 829,352 & 682,002 & $1,098,025$ & 943,069 & 769,729 & $1,158,624$ & $2,778,746$ & $1,079,937$ & 920,212 & $1,472,571$ \\
\hline Rural & $3,688,843$ & $3,019,121$ & 4,399,165 & $4,090,219$ & $2,959,505$ & $4,343,878$ & $11,819,912$ & $4,491,657$ & $3,349,910$ & $4,903,018$ \\
\hline Kampala & 349,699 & 307,450 & 509,638 & 374,777 & 356,253 & 493,032 & $1,034,379$ & 424,175 & 337,624 & $555,661.92$ \\
\hline Central & $1,122,866$ & 862,364 & $1,285,878$ & $1,169,493$ & 874,563 & $1,300,660$ & $3,319,804$ & $1,214,041$ & 985,021 & $1,546,452$ \\
\hline Eastern & $1,179,949$ & 935,914 & $1,402,516$ & $1,181,049$ & 835,481 & 1,219,932 & $3,885,892$ & $1,550,624$ & $1,161,006$ & $1,636,398$ \\
\hline Northern & 723,406 & 662,194 & 902,188 & 909,403 & 721,994 & $1,031,628$ & $2,770,595$ & 996,518 & 727,698 & $1,009,542$ \\
\hline Western & $1,142,276$ & 933,201 & $1,396,971$ & $1,398,566$ & 940,943 & $1,457,249$ & 3,587,989 & $1,386,237$ & $1,058,773$ & $1,627,535$ \\
\hline Total & $4,518,195$ & $3,701,122$ & $5,497,191$ & $5,033,287$ & $3,729,234$ & $5,502,502$ & $14,598,658$ & $5,571,594$ & $4,270,121$ & 6,375,588.92 \\
\hline
\end{tabular}

Source: Various rounds of the UNHS; 2002/03, 2005/06 and 2009/10

Table 2. Labour force by age cohorts, region and residence (Millions)

\begin{tabular}{|c|c|c|c|c|c|c|c|c|c|c|}
\hline & \multirow[b]{2}{*}{$15-24$} & \multicolumn{2}{|c|}{ UNHS 2002/03 } & \multicolumn{3}{|c|}{ UNHS 2005/06 } & \multirow[b]{2}{*}{$14-64$} & \multicolumn{3}{|c|}{ UNHS 2009/10 } \\
\hline & & $25-35$ & $18-30$ & $15-24$ & $25-35$ & $18-30$ & & $15-24$ & $25-35$ & $18-30$ \\
\hline Female & $1,636,690$ & $1,790,050$ & $2,619,922$ & $1,851,357$ & $1,726,242$ & $2,405,806$ & $7,014,310$ & $2,921,879$ & $2,217,979$ & $3,556,031$ \\
\hline Urban & 449,928 & 597,267 & 811,291 & 472,298 & 649,495 & 776,286 & $2,264,910$ & $1,149,459$ & $873,970.52$ & $1,472,571$ \\
\hline Rural & $2,467,947$ & $2,845,692$ & $3,801,540$ & $3,058,976$ & $2,753,585$ & 3,703,265 & $11,101,892$ & $4,181,079$ & $3,412,010$ & 4,903,018 \\
\hline Kampala & 205,090 & 269,997 & 382,424 & 173,000 & 290,536 & 321,387 & 815,674 & 434,614 & 316,378 & 555,662 \\
\hline Northern & 515,426 & 622,673 & 794,185 & 632,024 & 659,310 & $853,729.78$ & $2,598,421$ & 937,989 & 722,793 & $1,009,542$ \\
\hline Western & 716,699 & 874,282 & $1,167,981$ & $1,021,948$ & 875,148 & $1,221,298$ & $3,334,703$ & $1,330,143$ & $1,107,721$ & $1,627,535$ \\
\hline Total & 2,917,875 & $3,442,959$ & $4,612,831$ & $3,531,274$ & $3,403,080$ & $4,479,551$ & 13,366,802 & $5,330,538$ & $4,285,981$ & $6,375,589$ \\
\hline
\end{tabular}

Source: Various rounds of the UNHS; 2002/03, 2005/06 and 2009/10 
The Labor Force Participation Rate (LFPR) is the number of persons in the labor force expressed as a percentage of the working-age population (UNHS Report, 2009/10). It measures the extent to which a country's working age population (14-64 years) is economically active. It also gives an indication of how many people of working age are actively participating in the labor market and includes both the employed and unemployed (UNHS Report, 2009/10). Table 3 shows the Labor Force Participation Rate (LFPR) by sex, residence and region for the youth 15-24 years, 25-35 years and 18-30 years. The overall LFPR was 65 percent for the youth in the 15-24 years as of 2002/03 but later increased to $70 \%$ in 2005/06 and to $86 \%$ in 2009/10 (Table 3). This is an increase of over 20 percentage points for the period 2002-2010. However, this doesn't necessarily reflect more and better employment opportunities since most of the youths are forced to do any work in order diversify incomes in the face of very high poverty (Ministry of Education, Technical Report 1 2011). An important issue therefore that requires government attention is the productivity (in terms of earnings) and the intensity of work (time committed) that the majority of the youth population is involved in if the youths are to be lifted out of poverty. In the same vein there is a great loophole in the definition of employment being used by UBOS during the surveys. "Employment measures the number of people who work for an hour or more a week for pay or profit, or who work unpaid in a family business or farm". In reality, this leaves a big question concerning the usefulness of the income earned by an individual working for an hour a week or whether subsistence farm workers are also considered as employed. Whereas LFPR is informative of the extent to which the youth population is economically active, it does not shed light on whether they are actually working or not.

Table 3. Labor force participation rate by age cohorts, region and residence (percentage)

\begin{tabular}{|c|c|c|c|c|c|c|c|c|c|c|}
\hline & \multicolumn{3}{|c|}{ UNHS 2002/03 } & \multicolumn{3}{|c|}{ UNHS 2005/06 } & \multirow[b]{2}{*}{$14-64$} & \multicolumn{3}{|c|}{ UNHS 2009/10 } \\
\hline & $15-24$ & $25-35$ & $18-30$ & $15-24$ & $25-35$ & $18-30$ & & $15-24$ & $25-35$ & $18-30$ \\
\hline Male & 61.35 & 96.19 & 84.05 & 70.35 & 94.38 & 83.12 & 92.20 & 85.3 & 98.2 & 93.1 \\
\hline Female & 67.36 & 90.28 & 83.81 & 69.99 & 88.41 & 79.99 & 91.00 & 85.9 & 95.7 & 90.1 \\
\hline Urban & 54.25 & 87.58 & 73.89 & 50.08 & 84.38 & 67.00 & 81.5 & 68.5 & 94.3 & 81.3 \\
\hline Rural & 66.90 & 94.26 & 86.42 & 74.79 & 93.04 & 85.25 & 93.9 & 90.3 & 97.6 & 94.4 \\
\hline Kampala & 58.65 & 87.82 & 75.04 & 46.16 & 81.55 & 65.19 & 78.9 & 65.90 & 93.7 & 79.8 \\
\hline Central & 64.35 & 90.31 & 82.34 & 72.32 & 91.50 & 81.87 & 91.9 & 86.00 & 97.7 & 91.1 \\
\hline Eastern & 64.25 & 95.86 & 86.23 & 72.69 & 93.10 & 83.47 & 91.8 & 85.00 & 96.4 & 91.1 \\
\hline Northern & 71.25 & 94.03 & 88.03 & 69.50 & 91.32 & 82.76 & 93.8 & 90.20 & 97.9 & 94.5 \\
\hline Western & 62.74 & 93.69 & 83.61 & 73.07 & 93.01 & 83.81 & 92.9 & 89.20 & 97.2 & 94 \\
\hline Total & 64.58 & 93.02473 & 83.91 & 70.16 & 91.25 & 81.41 & 91.60 & 85.6 & 96.9 & 91.4 \\
\hline
\end{tabular}

Source: Various rounds of the UNHS; 2002/03, 2005/06 and 2009/10

The findings generally show an increase in the LFPR of both males and females for the youth by international definition (15-24 years). It is noteworthy that the labour force participation gap between males and females is not so huge suggesting some gender parity. For the period 2002/03 the labour force participation rate of female youths exceeded that of male youths by over six percentage points, in 2005/06, the labour force participation rate of male youths exceeded that of female youths by 0.36 percentage points and in 2009/10 the labour force participation rate of females exceeded that of males by 0.6 percentage points (Table 3). The fact that female labor force participation rate exceeded that of males for some periods should be interpreted with caution because it might be the case that there more females in the subsistence farm work compared to their male counterparts. Indeed, for other definitions of the youth; 25-35 years (old youths) and 18-30 years (national definition), the labor force participation rate of male youths consistently exceeds that of female youth for the entire period under 
study (2002-2010) (Table 3). This seems to be the convention in developing countries like Uganda where some married women do not participate in the labor force. As aforementioned, the differences are not so huge suggesting a tendency towards gender parity. This can be possibly attributed to the increased participation of women in higher education coupled with some affirmative action efforts that have enabled female youths to work outside their homes for pay. Considering the location of the youth and throughout all the definitions of the youth, there is a higher labor force participation rate for the youth in the rural than the youth in the urban areas. For those in the 15-24 years, as of 2002/03, the labor force participation rate of the youth in the rural area exceeded that of the urban area by 13 percentage points; in 2005/06 the labor force participation rate of the youth in the rural area exceeded that of the youth in urban area by 7 percentage points and in 2009/10, the labor force participation rate of the youth in rural exceeded that of the youth in urban by 3 percentage points. Again, these findings should be interpreted with caution. They don't necessarily imply that there are more gainful employment opportunities for the youth in the rural than the youth in the urban areas. It might be the case that the youth in the rural area find it easier to participate in subsistence agriculture, yet, it is not equally easy for the youth in urban areas to find a job. Observing the regional distribution of youth labor force participation rate, and for all definitions of the youth portrayed in Table 3, it's clear that the labor force participation rate of the youth in other regions far exceeds that of Kampala. A similar attribution might hold; in other regions that are more rural, it might be easier to obtain a job in such areas, especially in the subsistence agriculture. It might also be the case that the youth are forced to engage in any sort of livelihood activity, especially petty businesses in the informal sector, in order to make ends meet. The increase in the labor force participation rate for the age group 15-24 is especially worrying because many of these may not have completed education up to University level. This may exhibit poor quality of the labor force going by the education measure.

\subsection{Labor Force Quality: Education Attainment}

We use the educational attainment of individuals aged 15 years and over to draw insights on the quality of the labour force in the country. Table 4 shows the analysis of the education attainment by gender, location, and region. It is revealed that the percentage of youth 15-24 years without formal schooling declined from 11 percent in $2002 / 03$ to $6 \%$ in 2005/06 before rising slightly to 7 percent in 2009/10. Overall, this result implies an improvement in the quality of the youth labor force for the period 2002-2010. Those with some or completed primary school increased from $67 \%$ in $2002 / 03$ to $68 \%$ in $2005 / 06$ before declining to $64 \%$ in $2009 / 10$. On the other hand, those with some or completed secondary school increased from 20\% in 2002/03 to 24\% in 2005/06 before increasing to $26 \%$ in $2009 / 10$. In the same vein, those with postsecondary education (tertiary and university) declined from $2.8 \%$ in $2002 / 03$ to $2 \%$ in 2005/06 before increasing to $3 \%$ in 2009/10 (Table 4). The decline in the percentage of the youth (15-24 years) with no education and an increase in those with secondary and postsecondary education means that the youth labor force has become more educated and hence of higher quality. It should however be noted that the percentage of youth with postsecondary education still lags behind that of primary and secondary education an issue that has an important bearing on youth labor force quality. Individuals that have attained only primary or secondary education usually find a difficulty of being absorbed into formal employment.

By gender, for the youth in 15-24 years and for the period 2002/03, there are more female youths (14\%) with no education compared to their male counterparts $(7 \%)$. On the other hand there are more male youths with primary education (68\%) compared to their female counterparts (66\%). Additionally, there are more male youths with secondary education (22\%) compared to their female counterparts (18\%). On the contrary, there are slightly more female youth with postsecondary education (2.9\%) compared to their male counterparts $(2.6 \%)$. The proportion of the female youth with no education declined from 14\% in 2002/03 to 8\% in 2005/06 before rising to $10 \%$ in $2009 / 10$. The proportion of the male youth with no education declined from $7 \%$ in $2002 / 03$ to $4 \%$ in 2005/06 and remained the same in 2009/10. On the other hand, he proportion of the male youth with postsecondary education declined from $3 \%$ in $2002 / 03$ to $1 \%$ in 2005/06 before rising back to $3 \%$ in 2009/10. The same picture can be observed for the female youth for the period and level under consideration. Overall, apart from slight differences, there are no outstanding differences in the quality of the labor force between the female and male youths, hence pointing to gender parity in education. However, the proportion of the youth labor force with postsecondary education is very small pointing to a lower quality of the youth labor force.

Regional and location disparities exist in the education attainment of the youth labor force. The rural area, the northern and western regions have the poorest quality of the youth labour force in terms of education attainment particularly beyond secondary level (Table 4). As of 2002/03 12\% of the youth labor force in the rural areas had no education compared to only $5 \%$ of their urban counterparts. In 2005/06, the percentage declined implying an improvement in the quality of the labor force; $7 \%$ of the rural youth labor force had no education compared to 
only 3\% of the urban youth labor force. Surprisingly, the situation became worse in 2009/10; $8 \%$ of the rural youth labor force had no education compared to $4 \%$ of the urban counterparts. The situation is similar once we look at primary education, but it becomes completely different by observing secondary and postsecondary education. It is revealed that $36 \%$ of the youth labor force in urban areas attained secondary education compared to only $17 \%$ of their counterparts in the rural areas, yet, $7 \%$ of the youth labor force in the urban area attained postsecondary education compared to only $2 \%$ of their counterparts in the rural areas (as of 2002/03). The quality of the youth labor force improved drastically for the period 2005/06 and 2009/10 (Table 4). In 2005/06, $42 \%$ of the youth labor force in urban area attained secondary education compared to $21 \%$ of their counterparts in the rural areas. Additionally $7 \%$ of the youth labor force in urban areas attained postsecondary education compared to only $1 \%$ of their counterparts in the rural areas. In $2009 / 10,46 \%$ of the youth labor force in the urban area attained secondary education compared to $22 \%$ of their counterparts in the rural areas. Further, $9 \%$ of the youth labor force in the urban areas attained postsecondary education compared to only $2 \%$ of their counterparts in the rural areas. Overall, it's is clear that the overall quality of the youth labor force improved for the period under review (2002-2010), however, the quality of the youth labor force is higher for the youth in the urban area compared to the youth in the rural. It's noteworthy that there is a high proportion of the youth in the rural compared to the urban areas. This implies that a bigger cross-section of the youth in Uganda is of poor quality going by the level of education attained. Therefore, any set of policies designed to solve the problem of youth unemployment should include a package that is intended to impart some basic skills into the youth labor force; such skills like the Business, Technical, Vocational Education Training (BTVET) which is already taking place in Uganda should be strengthened and rolled out to reach all the youth in the different locations and regions. This will help the youth to have the capacity to start their own business as well as improving their employability.

Looking at the regional distribution of the youth educational attainment rates, for the period 2002/03, Kampala stands out of other regions with the lowest proportion of the youth with no education (3\% compared to $24 \%$ of the youth in Northern Uganda) and with primary education (48\% compared to $72 \%$ of the youth in Eastern Uganda). Conversely, Kampala stands out of other regions with the highest proportion of the youth with secondary and postsecondary education; $41 \%$ of the youth in Kampala attained secondary education compared to only 9\% in Northern Uganda and 8\% of the youth in Kampala attained postsecondary education compared to only 2\% in Eastern and Northern Uganda (Table 4, for the period 2002/03). For the subsequent periods 2005/06 and 2009/10, the labor force quality improved across the regions. In 2005/06, only $1 \%$ of the youth labor force in Kampala had no education compared to $12 \%$ in Northern Uganda, $42 \%$ of the youth labor force in Kampala had primary education compared to $76 \%$ in Northern Uganda. Additionally, $47 \%$ of the youth labor force in Kampala had secondary education compared to only $12 \%$ in Northern Uganda, $10 \%$ of the youth labor force in Kampala had postsecondary education compared to $1 \%$ in Northern Uganda. In 2009/10, $2 \%$ of the youth Labor force in Kampala had no education compared to $12 \%$ of their counterparts in Northern Uganda, $34 \%$ of the youth labor force in Kampala had primary education compared to $73 \%$ of their counterparts in Eastern Uganda. Additionally, $53 \%$ of the youth labor force in Kampala had secondary education compared to $19 \%$ of counterparts in Northern Uganda, $12 \%$ of the youth labor force in Kampala had postsecondary education compared to $1 \%$ in Eastern Uganda. Overall, the quality of the youth labor force improved across all regions of Uganda; however, Kampala has the highest quality of the youth labor force. Since Kampala has the smallest proportion of the youth, efforts that go beyond Kampala are needed to improve the quality of the majority of the youth in other regions of the country. Similar observations can be drawn from other definitions of the youth labor force (18-30 and 25-35 years) (Table 4).

Table 4. Education of the Labor force by age cohorts, region and residence (percentage)

\begin{tabular}{|c|c|c|c|c|c|c|c|c|c|c|c|c|}
\hline \multirow{2}{*}{$\begin{array}{l}\text { Age } \\
\text { group: } \\
\text { 14-64 }\end{array}$} & \multicolumn{4}{|c|}{ UNHS 2002/03 } & \multicolumn{4}{|c|}{ UNHS 2005/06 } & \multicolumn{4}{|c|}{ UNHS 2009/10 } \\
\hline & $N E^{[1]}$ & $\mathbf{P}^{[2]}$ & $S^{[3]}$ & $\mathbf{P} \mathbf{S}^{[4]}$ & $\mathbf{N E}$ & $\mathbf{P}$ & S & P S & N E & $\mathbf{P}$ & $\mathrm{S}$ & P S \\
\hline Male & 10.39 & 60.97 & 21.41 & 7.22 & 6.97 & 63.58 & 22.65 & 6.8 & 8.22 & 60.08 & 22.87 & 8.83 \\
\hline Female & 25.12 & 56.57 & 14.43 & 3.87 & 21.68 & 59.17 & 15.29 & 3.86 & 21.75 & 57.58 & 15.14 & 5.53 \\
\hline Urban & 6.82 & 44.78 & 33.7 & 14.7 & 5.76 & 44.49 & 35.57 & 14.18 & 5.43 & 38.35 & 34.67 & 21.55 \\
\hline Rural & 20.1 & 61.08 & 14.97 & 3.86 & 16.04 & 64.3 & 15.93 & 3.72 & 17.34 & 62.9 & 15.59 & 4.17 \\
\hline
\end{tabular}




\begin{tabular}{|c|c|c|c|c|c|c|c|c|c|c|c|c|}
\hline Kampala & 3.81 & 39.63 & 38.68 & 17.88 & 1.91 & 39.63 & 41.84 & 16.62 & 3.68 & 34.91 & 40.76 & 20.65 \\
\hline Central & 11.17 & 61.48 & 22.65 & 4.71 & 9.01 & 60.47 & 24.85 & 5.68 & 8.7 & 54.75 & 26.28 & 10.27 \\
\hline Eastern & 17.29 & 63.36 & 15.9 & 3.45 & 13.23 & 63.48 & 18.66 & 4.63 & 15.38 & 65.04 & 15.46 & 4.11 \\
\hline Northern & 31.95 & 55.2 & 9.47 & 3.37 & 21.04 & 63.6 & 11.83 & 3.53 & 21.64 & 59.59 & 12.54 & 6.23 \\
\hline Western & 19.06 & 58.27 & 15.93 & 6.75 & 18.73 & 63.13 & 13.76 & 4.39 & 19.27 & 60.91 & 15.08 & 4.73 \\
\hline Total & 18.13 & 58.66 & 17.75 & 5.46 & 14.5 & 61.32 & 18.88 & 5.3 & 15.34 & 58.77 & 18.8 & 7.09 \\
\hline \multicolumn{13}{|l|}{$\begin{array}{l}\text { Age } \\
\text { group: } \\
15-24\end{array}$} \\
\hline Male & 7.3 & 68.35 & 21.74 & 2.61 & 3.69 & 69.88 & 25.03 & 1.39 & 3.62 & 65.86 & 27.65 & 2.87 \\
\hline Female & 13.66 & 65.6 & 17.8 & 2.94 & 8.37 & 66.48 & 23.07 & 2.08 & 9.56 & 62.41 & 24.95 & 3.07 \\
\hline Urban & 5.13 & 52.44 & 35.67 & 6.75 & 2.56 & 49.04 & 41.9 & 6.49 & 3.84 & 41.66 & 45.98 & 8.52 \\
\hline Rural & 11.9 & 69.42 & 16.6 & 2.08 & 6.7 & 71.03 & 21.24 & 1.02 & 7.51 & 68.53 & 22.11 & 1.84 \\
\hline Kampala & 3.21 & 47.89 & 40.62 & 8.28 & 1.02 & 42.22 & 47.26 & 9.50 & 1.75 & 33.49 & 52.75 & 12.01 \\
\hline Central & 6.06 & 65.74 & 25.04 & 3.16 & 3.36 & 61.90 & 33.12 & 1.62 & 3.87 & 57.14 & 35.98 & 3 \\
\hline Eastern & 9.83 & 71.58 & 17.06 & 1.53 & 3.76 & 67.70 & 27.32 & 1.22 & 5.23 & 72.56 & 20.81 & 1.4 \\
\hline Northern & 23.49 & 65.96 & 8.89 & 1.65 & 11.53 & 75.94 & 11.57 & 0.96 & 11.64 & 67.13 & 18.49 & 2.75 \\
\hline Western & 9.82 & 68.82 & 18.32 & 3.04 & 8.00 & 73.09 & 17.42 & 1.49 & 9.02 & 65.88 & 22.51 & 2.59 \\
\hline Total & 10.86 & 66.81 & 19.54 & 2.8 & 6.15 & 68.09 & 24 & 1.76 & 6.89 & 63.96 & 26.17 & 2.98 \\
\hline
\end{tabular}

\begin{tabular}{|c|c|c|c|c|c|c|c|c|c|c|c|c|}
\hline \multirow{2}{*}{$\begin{array}{l}\text { Age } \\
\text { group: } \\
25-35\end{array}$} & \multicolumn{4}{|c|}{ UNHS 2002/03 } & \multicolumn{4}{|c|}{ UNHS 2005/06 } & \multicolumn{4}{|c|}{ UNHS 2009/10 } \\
\hline & N E & $\mathbf{P}$ & $\mathbf{S}$ & P S & N E & $\mathbf{P}$ & S & P S & N E & $\mathbf{P}$ & $\mathbf{S}$ & P S \\
\hline Male & 8.72 & 58.63 & 23.03 & 9.62 & 5.94 & 59.67 & 24.9 & 9.49 & 8.89 & 55.11 & 23.85 & 12.14 \\
\hline Female & 23.12 & 56.03 & 15.57 & 5.28 & 21.38 & 57.35 & 15.09 & 6.18 & 21.02 & 56.69 & 13.36 & 8.93 \\
\hline Urban & 5.79 & 41.97 & 34.33 & 17.92 & 3.92 & 40.89 & 38.44 & 16.74 & 3.92 & 36.99 & 29.21 & 29.88 \\
\hline Rural & 18.41 & 60.48 & 15.96 & 5.15 & 16.09 & 62.64 & 15.57 & 5.71 & 17.86 & 60.6 & 15.84 & 5.7 \\
\hline Kampala & 3.94 & 38.48 & 36.77 & 20.81 & 1.56 & 36.08 & 43.91 & 18.45 & 3.00 & 32.32 & 36.05 & 28.63 \\
\hline Central & 9.76 & 60.63 & 24.39 & 5.22 & 9.7 & 58.26 & 24.62 & 7.42 & 8.20 & 50.59 & 25.21 & 16.00 \\
\hline Eastern & 15.89 & 62.32 & 17.08 & 4.7 & 13.51 & 63.15 & 16.6 & 6.74 & 16.38 & 63.20 & 15.99 & 4.43 \\
\hline Northern & 29.79 & 54.91 & 11.02 & 4.28 & 19.42 & 61.97 & 13.35 & 5.26 & 20.45 & 60.63 & 9.91 & 9.01 \\
\hline Western & 16.36 & 56.57 & 17.02 & 10.05 & 17.52 & 59.42 & 15.56 & 7.5 & 19.80 & 56.58 & 15.81 & 7.81 \\
\hline Total & 16.22 & 57.27 & 19.14 & 7.36 & 13.77 & 58.49 & 19.93 & 7.81 & 15.09 & 55.92 & 18.49 & 10.5 \\
\hline
\end{tabular}




\begin{tabular}{|c|c|c|c|c|c|c|c|c|c|c|c|c|}
\hline $\begin{array}{l}\text { Age } \\
\text { group: } \\
18-30\end{array}$ & & & & & & & & & & & & \\
\hline Male & 8.16 & 60.9 & 23.93 & 7.01 & 5.18 & 61.93 & 27.99 & 4.9 & 6.92 & 54.49 & 30.2 & 8.39 \\
\hline Female & 17.14 & 61.04 & 17.3 & 4.52 & 14.47 & 60.89 & 19.89 & 4.75 & 14.57 & 57.22 & 21.42 & 6.79 \\
\hline Urban & 5.68 & 45.43 & 35.51 & 13.38 & 3.00 & 43.66 & 40.74 & 12.60 & 2.83 & 37.27 & 39.34 & 20.56 \\
\hline Rural & 14.88 & 64.28 & 16.9 & 3.94 & 11.67 & 65.07 & 20.06 & 3.19 & 13.27 & 61 & 21.77 & 4.14 \\
\hline Kampala & 3.85 & 41.87 & 37.9 & 16.37 & 0.61 & 37.61 & 46.2 & 15.58 & 2.63 & 30.59 & 45.18 & 21.61 \\
\hline Central & 7.9 & 61.3 & 26.12 & 4.68 & 6.76 & 58.48 & 30.41 & 4.35 & 6.12 & 50.51 & 33.07 & 10.3 \\
\hline Eastern & 13.28 & 66.31 & 17.32 & 3.09 & 8.33 & 63.45 & 24.42 & 3.8 & 11.18 & 65.13 & 20.56 & 3.13 \\
\hline Northern & 25.56 & 60.32 & 10.82 & 3.3 & 14.31 & 68.67 & 14.14 & 2.89 & 17.13 & 59.24 & 17.3 & 6.33 \\
\hline Western & 12.77 & 61.8 & 18.34 & 7.08 & 14.31 & 63.33 & 17.78 & 4.58 & 14.43 & 57.47 & 22.25 & 5.85 \\
\hline Total & 13.27 & 60.98 & 20.16 & 5.6 & 10.17 & 61.37 & 23.64 & 4.82 & 11.13 & 55.99 & 25.37 & 7.51 \\
\hline
\end{tabular}

Source: Various rounds of the UNHS; 2002/03, 2005/06 and 2009/10

${ }^{[1]}$ No Education; ${ }^{[2]}$ Primary; ${ }^{[3]}$ Secondary; ${ }^{[4]}$ Post Secondary

\subsection{Youth Total Employment and Employment to Population Ratio}

The total number of the youth (15-24 years) employed increased from 2.8 million in 2002/03 to 3.4 million in 2005/06 and to 4.4 million in 2009/10, an issue that indicates increased absorption of the youth in economic activities. The growth rate of the employed youth was 21\% between 2002 and 2005 and it grew to 29\% between 2005 and 2010 (Table 5). However, this high growth rate of employment should be interpreted with caution because a number of youth workers are forced by poverty to engage in any economic activity, like petty trading in the informal sector, in order to make ends meet. Such activities in the informal sector are characterized by low work intensity and low productivity in terms of the revenue generated. It doesn't necessarily mean an increase in gainful employment opportunities in the country. By gender, for the youth 15-24 years (as of 2002/03), there were 1.6 million female youths employed compared to 1.2 million male youths employed. In 2005/06, there was an increase in the number of both male and female youths employed but still the female employed youths outnumbered their male counterparts. There were 1.8 million female employed youth compared to 1.6 million employed male youths. In 2009/10, there was a drastic increase in both female and male employed youths; there were 2.4 million employed female youth compared to 2 million male employed youth. A similar picture can be observed for other definitions of the youth considered in this study (18-30 years and 25-35 years). However, the increased employment of the female youth should be interpreted with caution since it might be the fact that there are more females than males in the subsistence agriculture, an issue that might not necessarily mean an increase in gainful employment for the female youths. In the same line of argument, there are more employed youth in the rural (2.4 million) compared to urban area (only 0.4 million) (as of 2002/03). In 2005/06, the youth employed in rural areas increased to 3 million compared to 0.41 million employed in urban areas. In 2005/06, the youth employed in the rural areas increased to 3.7 million compared to 0.7 million employed in urban areas. A similar pictured can be observed for other definitions of the youth considered in this study. Again, these results might imply that the youth in rural areas can easily get engaged in the subsistence agriculture, but it is not equally easy to be absorbed in employment in the urban areas. The results therefore might not imply an increase in gainful/productive employment in the rural areas compared to urban areas. An important policy implication is to improve the productivity of the agricultural sector if the youth in the rural areas are to be lifted out of poverty. Looking at the regional distribution, the findings are in line with those above; rural regions have a higher proportion of the youth employed compared to urban regions, especially Kampala (Table 5). The aforementioned policy implication applies in this case.

We also computed the Employment to Population Ratio (EPR) for the youth defined as total employment of the youth aged 15-24 years as a percentage of the total population in the same age group (UNHS Report, 2005/06 
and 2009/10). This ratio indicates the extent to which the youths are involved in productive labor market activities. It also presents an indication on how the economy generates work. It is revealed that EPR for the youth 15-24 years increased drastically from 62 percent in 2002/03 to 68 percent in 2005/06 and to 82\% in 2009/10 (Table 6). This implies that youths became increasingly involved in productive market activities for the period of time under review (2002-2010). Considering the gender dimension, in 2002/03, female youths have a higher EPR of 64\% compared to 59\% of their male counterparts; in 2005/06, the EPR of the female youths was slightly lower (68\%) than that of their male counterparts (69\%). In 2009/10, the EPR of both the male and female youth increased drastically and they became more similar with just a very small difference between them (0.3 percentage points). Both the rural and urban areas experienced an increase in the EPR for the period 2002-2010. However, the EPR of the rural area is above that of the urban area during the same period (Table 6). This means that persons in rural areas were more likely to get employed than those in urban areas. This might be attributed to the fact that rural activities especially in agriculture do not require highly specialized skills once compared to those in the urban areas. This is coupled by the fact that there is a high influx of educated youth in urban areas in search of wage and salary employment which is rather limited in developing countries like Uganda. This has made urban unemployment significant. There are also regional variations in the EPR. All regions experienced an increase in the EPR between 2002 and 2010 meaning that the economy created more employment. Considering the youth (15-24 years) Kampala had the lowest rate; 44\% in 2002/03 compared to the highest of $71 \%$ in Northern Uganda, 38\% in 2005/06 compared to the highest of 72\% in Eastern and Western Uganda, $56 \%$ in 2009/10 compared to the highest of $88 \%$ in Western Uganda (Table 6). In order to increase the proportion of the population that is employed, government effort is called for to create gainful employment opportunities especially in regions at an extreme disadvantage, particularly Kampala. But other regions also require due consideration of raising the productivity of the types of work undertaken by the youth; some of them might be in subsistence agriculture which is not a gainful employment. A similar phenomenon can be observed for other definitions of the youth; 25-35 years and 18-30 years.

Table 5. Total Employment by age cohorts, region and residence (Millions)

\begin{tabular}{lllllllllll}
\hline \multicolumn{1}{l}{ UNHS 2002/03 } & \multicolumn{9}{c}{ UNHS 2005/06 } & \multicolumn{5}{c}{ UNHS 2009/10 } \\
& $\mathbf{1 5 - 2 4}$ & $\mathbf{2 5 - 3 5}$ & $\mathbf{1 8 - 3 0}$ & $\mathbf{1 5 - 2 4}$ & $\mathbf{2 5 - 3 5}$ & $\mathbf{1 8 - 3 0}$ & $\mathbf{1 4 - 6 4}$ & $\mathbf{1 5 - 2 4}$ & $\mathbf{2 5 - 3 5}$ & $\mathbf{1 8 - 3 0}$ \\
\hline Male & $1,238,946$ & $1,610,220$ & $1,930,773$ & $1,637,707$ & $1,644,473$ & $2,017,906$ & $6,193,011$ & $1,990,089$ & $1,984,998$ & $2,548,210$ \\
Female & $1,553,860$ & $1,755,511$ & $2,514,043$ & $1,784,184$ & $1,688,607$ & $2,317,816$ & $6,696,491$ & $2,404,586$ & $2,002,690$ & $3,025,638$ \\
& & & & & & & & & & \\
Urban & 376,273 & 554,907 & 711,478 & 410,300 & 614,395 & 696,358 & $2,066,828$ & 698,635 & 759,407 & $1,064,151$ \\
Rural & $2,416,533$ & $2,810,824$ & $3,733,338$ & $3,011,591$ & $2,718,685$ & $3,639,365$ & $10,822,674$ & $3,696,040$ & $3,228,280$ & $4,509,698$ \\
& & & & & & & & & & \\
Kampala & 152,531 & 248,563 & 320,736 & 142,581 & 271,421 & 281,448 & 728,618 & 243,752 & 271,050 & 381,581 \\
Central & 682,049 & 752,220 & $1,006,152$ & 818,358 & 785,713 & $1,026,281$ & $2,895,467$ & 961,344 & 893,387 & $1,308,726$ \\
Eastern & 738,062 & 884,689 & $1,182,988$ & 849,359 & 772,417 & $1,007,230$ & $3,480,570$ & $1,208,695$ & $1,078,994$ & $1,454,624$ \\
Northern & 512,465 & 617,640 & 787,455 & 599,286 & 635,906 & 813,181 & $2,509,186$ & 814,409 & 685,353 & 922,078 \\
Western & 707,699 & 862,619 & $1,147,485$ & $1,012,308$ & 867,623 & $1,207,582$ & $3,275,661$ & $1,166,475$ & $1,058,904$ & $1,506,838$ \\
& & & & & & & & & & \\
Total & $2,792,806$ & $3,365,731$ & $4,444,816$ & $3,421,892$ & $3,333,080$ & $4,335,723$ & $12,889,501$ & $4,394,675$ & $3,987,687$ & $5,573,848$ \\
\hline
\end{tabular}

Source: Various rounds of the UNHS; 2002/03, 2005/06 and 2009/10

Table 6. Employment to Population ratio by age cohorts, region and residence (percentage)

\begin{tabular}{lcccccccccc}
\hline & \multicolumn{3}{c}{ UNHS 2002/03 } & \multicolumn{3}{c}{ UNHS 2005/06 } & \multicolumn{4}{c}{ UNHS 20092/10 } \\
& $\mathbf{1 5 - 2 4}$ & $\mathbf{2 5 - 3 5}$ & $\mathbf{1 8 - 3 0}$ & $\mathbf{1 5 - 2 4}$ & $\mathbf{2 5 - 3 5}$ & $\mathbf{1 8 - 3 0}$ & $\mathbf{1 4 - 6 4}$ & $\mathbf{1 5 - 2 4}$ & $\mathbf{2 5 - 3 5}$ & $\mathbf{1 8 - 3 0}$ \\
\hline Male & 59.32 & 93.71 & 81.43 & 68.58 & 92.56 & 80.88 & 89.9 & 82.6 & 96.0 & 90.4 \\
Female & 63.95 & 88.54 & 80.42 & 67.45 & 86.48 & 77.06 & 86.8 & 82.3 & 90.3 & 85.1 \\
\hline
\end{tabular}




\begin{tabular}{lccccccccccc} 
Urban & 45.37 & 81.36 & 64.8 & 43.51 & 79.82 & 60.1 & 74.4 & 60.8 & 86.9 & 92.0 \\
Rural & 65.51 & 93.1 & 84.86 & 73.63 & 91.86 & 83.78 & 91.6 & 88.4 & 94.6 & 72.3 \\
& & & & & & & & & & \\
Kampala & 43.62 & 80.85 & 62.93 & 38.04 & 76.19 & 57.09 & 70.4 & 56.1 & 85.70 & 68.7 \\
Central & 60.74 & 87.23 & 78.25 & 69.98 & 89.84 & 78.9 & 87.2 & 81.6 & 90.60 & 84.6 \\
Eastern & 62.55 & 94.53 & 84.35 & 71.92 & 92.45 & 82.56 & 89.6 & 83.4 & 93.60 & 88.9 \\
Northern & 70.84 & 93.27 & 87.28 & 65.9 & 88.08 & 78.83 & 90.6 & 86.8 & 94.80 & 91.3 \\
Western & 61.96 & 92.44 & 82.14 & 72.38 & 92.21 & 82.87 & 91.3 & 87.7 & 95.60 & 92.6 \\
Total & 61.81 & 90.94 & 80.86 & 67.99 & 89.38 & 78.8 & 88.3 & 82.4 & 93.00 & 87.4 \\
\hline
\end{tabular}

Source: Various rounds of the UNHS; 2002/03, 2005/06 and 2009/10

\subsection{Status in Employment}

This subsection helps us draw insights on the type of youth workers found in the economy. Employment status is broadly categorized into two groups, namely self-employed and paid employees. UBOS defines self-employed to include employers, who could create jobs for others; own account workers, and unpaid family workers who assist in the household enterprises. The paid employees include permanent and temporary employees (UNHS Report 2009/10). The proportion of the youth workers 15-24 years that is self-employed in agriculture increased from $68 \%$ in $2002 / 03$ to $77 \%$ in $2005 / 06$ before declining to $69 \%$ in $2009 / 10$ (Table 7 ). On the other hand, the proportion of the youth workers self-employed in non-agriculture declined from $17 \%$ in 2002/03 to $9 \%$ in $2005 / 06$ before rising to $12 \%$ in $2009 / 10$. On the contrary, the proportion of the youth workers in paid employment declined from $15 \%$ in $2002 / 03$ to $14 \%$ in $2005 / 06$ before rising to $19 \%$ in $2009 / 10$. A similar picture can be drawn for other definitions of the youth considered; 25-35 years and 18-30 years. There are also discernible gender differences in the status of employment. There are more female youths self-employed in agriculture compared to their male counterparts for the entire period under study (2002-2010). In 2002/03 61\% of the male youth (15-24 years) were self employed in agriculture compared $75 \%$ of their female counterparts. In $2005 / 06,71 \%$ of male youth were self-employed in agriculture compared to $83 \%$ of their female counterparts. In 2009/10, there was a general reduction in the percentage of youth self-employed in agriculture, despite this, the percentage of the female youth (72\%) was higher than that of the male youth (69\%). The same picture can be observed for other definitions of the youth considered in our analysis. The proportion of the male youth (15-24 years) self-employed in non-agriculture $(18 \%)$ is higher than that of their female counterparts $(15 \%)$ for the period 2002/03. For the period 2005/06, the proportion of male and female youth self-employed in non-agriculture declined drastically to $9 \%$ and $8 \%$, respectively, before rising to $11 \%$ and $13 \%$ for male and female youth, respectively, in the period 2009/10. Compared to their male counterparts, the proportion of the female youth in paid employment is much lower. It can be observed from Table 7 that $21 \%$ of the male youth in the age bracket $15-24$ years are in paid employment compared to only $10 \%$ of their female counterparts for the period 2002/03. For the period 2005/06, 20\% of the male youth were in paid employment compared to $10 \%$ of their female counterparts. The proportion of both female and male youth in paid employed increased to $15 \%$ and $24 \%$, respectively, for the period 2009/10. Considering the location of the youth in relation to the employment status, there is a high portion of the youth self-employed in agriculture in the rural than in the urban area and the reverse is true for the youth self-employed in non-agriculture for the period 2002-2006 (Table 7). For the period 2009/10, the unexpected is observed; there is a high proportion of the youth self-employed in agriculture in the urban compared to the rural areas and a high proportion of the youth self-employed in non-agriculture in the rural compared to the urban areas. Considering paid employment, there is a high proportion of the youth in paid employment in the urban compared to the rural area for the period 2002-2006 (Table 7). In 2009/10, unexpectedly, the proportion of the youth in paid employment is higher in rural than in the urban setting. Considering the regional distribution, for the period 2002-2010, as expected, Kampala has the lowest proportion of the youth self-employed in agriculture and the highest proportion of the youth in paid employment compared to all other regions. Additionally, compared to all other regions, Kampala has the highest proportion of the youth self-employed in non-agriculture; this is again in line with the expectation. Other regions compared; Central, 
Eastern, Northern, and Western, compared to Kampala, have higher percentages of the youth self-employed in agriculture (with an average towards 70\%) compared to self-employment in non-agriculture and paid employment for the period 2002-2010. The observed proportion of the workforce in self-employment is quite significant and it is an indication of low growth in the formal economy and high rate of job creation in the informal economy. A situation where a large proportion of the employed is constituted by unpaid family workers is a probable indicator of poor development, limited job creation, widespread poverty and often a large rural economy (UNHS Report, 2005/06). The policy implication is that government should target to raise the productivity of agricultural activities where the majority of the youth labor force is located. Due to the limited expansion of paid jobs, improving the productivity of informal activities where the majority is located might be the optimal strategy.

Table 7. Status of employment by age cohorts (percentage)

\begin{tabular}{|c|c|c|c|c|c|c|c|c|c|}
\hline & \multicolumn{3}{|c|}{ UNHS 2002/2003 } & \multicolumn{3}{|c|}{ UNHS 2005/2006 } & \multicolumn{3}{|c|}{ UNHS $2009 / 2010$} \\
\hline & $15-24$ & $25-35$ & $18-30$ & $15-24$ & $25-35$ & 18-30 & $15-24$ & $25-35$ & 18-30 \\
\hline Self employed in agriculture & 68.07 & 55.55 & 59.71 & 76.97 & 59.97 & 65.79 & 68.88 & 54.46 & 57.39 \\
\hline Self employed in non-agriculture & 16.51 & 27.37 & 23.21 & 8.49 & 17.25 & 13.38 & 11.91 & 20.21 & 16.90 \\
\hline Paid employment & 15.42 & 17.08 & 17.09 & 14.54 & 22.78 & 20.84 & 19.21 & 25.33 & 25.71 \\
\hline Total & 100 & 100 & 100 & 100 & 100 & 100 & 100 & 100 & 100 \\
\hline \multicolumn{10}{|l|}{ Male } \\
\hline Self employed in agriculture & 60.67 & 43.26 & 47.17 & 70.96 & 49.02 & 55.49 & 64.98 & 43.29 & 47.9 \\
\hline Self employed in non-agriculture & 17.99 & 32.37 & 27.77 & 9.19 & 17.67 & 14.17 & 11.31 & 21.56 & 17.82 \\
\hline Paid employment & 21.34 & 24.37 & 25.06 & 19.84 & 33.31 & 30.33 & 23.71 & 35.15 & 34.28 \\
\hline Total & 100 & 100 & 100 & 100 & 100 & 100 & 100 & 100 & 100 \\
\hline \multicolumn{10}{|l|}{ Female } \\
\hline Self employed in agriculture & 74.45 & 67.67 & 70.07 & 82.49 & 70.67 & 74.77 & 71.88 & 65.61 & 65.25 \\
\hline Self employed in non-agriculture & 15.14 & 22.03 & 19.20 & 7.85 & 16.84 & 12.68 & 12.76 & 19.28 & 16.71 \\
\hline Paid employment & 10.41 & 10.3 & 10.73 & 9.66 & 12.48 & 12.55 & 15.36 & 15.11 & 18.04 \\
\hline Total & 100 & 100 & 100 & 100 & 100 & 100 & 100 & 100 & 100 \\
\hline \multicolumn{10}{|l|}{ Urban } \\
\hline Self employed in agriculture & 12.91 & 10.05 & 9.61 & 27.69 & 14.04 & 17.49 & 16.57 & 7.57 & 8.78 \\
\hline Self employed in non-agriculture & 41.14 & 48.95 & 46.22 & 24.73 & 38.35 & 31.94 & 36.58 & 38.36 & 36.56 \\
\hline Paid employment & 45.95 & 41.00 & 44.17 & 47.58 & 47.61 & 50.57 & 46.85 & 54.07 & 54.66 \\
\hline Total & 100 & 100 & 100 & 100 & 100 & 100 & 100 & 100 & 100 \\
\hline \multicolumn{10}{|l|}{ Rural } \\
\hline Self employed in agriculture & 76.83 & 64.73 & 69.36 & 83.66 & 70.36 & 75.00 & 8.60 & 0.00 & 2.34 \\
\hline Self employed in non-agriculture & 12.60 & 22.78 & 18.63 & 6.29 & 12.48 & 9.84 & 36.95 & 46.31 & 40.58 \\
\hline Paid employment & 10.57 & 12.5 & 12.01 & 10.05 & 17.16 & 15.16 & 54.44 & 53.69 & 57.09 \\
\hline Total & 100 & 100 & 100 & 100 & 100 & 100 & 100 & 100 & 100 \\
\hline \multicolumn{10}{|l|}{ Kampala } \\
\hline Self employed in agriculture & 3.75 & 2.66 & 1.59 & 0.86 & 2.18 & 0.61 & 8.60 & 0.00 & 2.34 \\
\hline Self employed in non-agriculture & 46.37 & 49.26 & 48.67 & 30.32 & 40.97 & 34.96 & 36.95 & 46.31 & 40.58 \\
\hline Paid employment & 49.88 & 48.07 & 49.75 & 68.82 & 56.85 & 64.43 & 54.44 & 53.69 & 57.09 \\
\hline Total & 100 & 100 & 100 & 100 & 100 & 100 & 100 & 100 & 100 \\
\hline \multicolumn{10}{|l|}{ Central } \\
\hline Self employed in agriculture & 63.35 & 53.50 & 55.05 & 69.57 & 50.54 & 55.29 & 54.42 & 39.02 & 42.07 \\
\hline
\end{tabular}




\begin{tabular}{lccccccccc}
\hline Self employed in non-agriculture & 17.99 & 28.15 & 24.85 & 11.03 & 21.58 & 17.27 & 19.06 & 28.47 & 24.39 \\
Paid employment & 18.66 & 18.35 & 20.10 & 19.4 & 27.87 & 27.44 & 26.52 & 32.51 & 33.54 \\
Total & 100 & 100 & 100 & 100 & 100 & 100 & 100 & 100 & 100 \\
Eastern & & & & & & & & & \\
Self employed in agriculture & 78.01 & 68.25 & 72.22 & 87.98 & 75.58 & 80.26 & 79.89 & 68.60 & 72.17 \\
Self employed in non-agriculture & 14.26 & 21.82 & 18.09 & 5.83 & 10.69 & 9.01 & 6.00 & 14.79 & 10.89 \\
Paid employment & 7.72 & 9.93 & 9.69 & 6.19 & 13.73 & 10.72 & 14.12 & 16.61 & 16.94 \\
Total & 100 & 100 & 100 & 100 & 100 & 100 & 100 & 100 & 100 \\
Northern & & & & & & & & & \\
Self employed in agriculture & 81.73 & 61.58 & 69.95 & 82.6 & 68.82 & 74.07 & 81.53 & 71.10 & 73.45 \\
Self employed in non-agriculture & 9.03 & 24.97 & 18.20 & 7.45 & 14.57 & 11.64 & 11.30 & 12.98 & 14.50 \\
Paid employment & 9.24 & 13.45 & 11.85 & 9.95 & 16.61 & 14.29 & 7.17 & 15.92 & 12.04 \\
Total & 100 & 100 & 100 & 100 & 100 & 100 & 100 & 100 & 100 \\
Western & & & & & & & & & \\
Self employed in agriculture & 67.9 & 56.45 & 61.3 & 81.13 & 66.34 & 72.31 & 72.76 & 56.2 & 60.27 \\
Self employed in non-agriculture & 15.73 & 26.50 & 22.38 & 6.21 & 13.66 & 9.83 & 8.05 & 17.56 & 12.83 \\
Paid employment & 16.37 & 17.06 & 16.32 & 12.66 & 20.00 & 17.86 & 19.19 & 26.24 & 26.9 \\
Total & 100 & 100 & 100 & 100 & 100 & 100 & 100 & 100 & 100 \\
\hline
\end{tabular}

Source: Various rounds of the UNHS; 2002/03, 2005/06 and 2009/10

\subsection{Industry and Sector of Employment}

This subsection helps us draw insights on the sectoral and industrial location of the youth labor force. We explore the sectors driving growth of the economy in relation to its employment potential to establish whether there is growth with jobs or jobless growth. This is a very important indicator of whether the majority of the youth benefit from economic growth via employment. It is noted from table 8 that there has been no shift in the sectoral composition of employment as agriculture, forestry and fishing remained the major sector of employment for the youth increasing from 72 percent in 2002/03 to 82 percent in 2005/06 before declining slightly to $74 \%$ in $2009 / 10$. On the other hand, the proportion of the youth labor force employed in the manufacturing sector declined from $6 \%$ in 2002/03 to 5\% in 2005/06 before increasing again to 7\% in 2009/10 (Table 9). Similarly, the proportion of the youth labor force employed in the services sector declined from $22 \%$ in $2002 / 2003$ to $14 \%$ in $2005 / 06$ before increasing slightly to $19 \%$ in $2009 / 10$ (Table 9). This scenario is worrying given that a higher proportion of the youth labor force is located in agriculture whose contribution to GDP declined so drastically (comparing Table 9 and 10). On the other hand, a lower proportion of the youth labour force is in services whose contribution to GDP increased drastically (compare Table 9 and 10). Employment in sectors such as trade, transport, and personal services tend to be self-employment or family businesses. Also, high capital intensity in some sectors such as transport and energy explains the low rate of job creation (Fox and Gaal, 2008). The implication of this scenario is abject poverty for all those working in a sector whose contribution to growth is dismal. It also implies that the quality of growth in the country does not favor job creation; it is a jobless growth. A publication by the Ministry of Finance and Economic Development reports a composite employment elasticity of 0.142 for the period 2002-2007. This suggests that for every one percentage point growth in GDP, employment increased by only 0.14 of a percentage point. This can be loosely interpreted to mean that growth over this period has been associated with low employment intensity. The policy option should target raising productivity in the agricultural sector where the majority of the young workers are located.

Looking at the gender differences, for the period 2002-2010, there is a higher proportion of female youth employed in agriculture compared to their male counterparts (Table 8). Conversely, there is a higher proportion of male youth employed in trade, manufacturing, and transport and communication sectors compared to their female counter parts for the entire period under review (Table 8). On the other hand, there are more female youth employed in Hotels, Restaurants and bars compared to their male counterparts for the entire period under review. The differences in the industries of employment between female and male youths imply that policy makers must 
be mindful of these differences while designing policies that can impact both groups equally. Considering the location of the youth, there is a higher proportion of the youth employed in agriculture in rural than urban areas of Uganda for the entire period reviewed. On the contrary, there is a higher proportion of the youth employed in trade, manufacturing, transport and communication, hotels and restaurants and bars, as well as in education in the urban compared to the rural areas of Uganda. This means that agriculture tends to dominate in employing the youth workers in the rural areas and other sectors dominate in the urban areas and this is very important for policy such that a package of policies fitting the youth in urban are very different from that package fitting the youth in the rural. Looking at the regional distribution, in Kampala, industries such as trade, manufacturing, transport and communications, hotels and restaurants employ more youth workers compared to agriculture. Conversely, in other regions (Central, Eastern, Northern, and Western) there is a higher proportion of the youth workers employed in Agriculture compared to other industries. These findings are as expected. This means that the youth in the different locations and regions are employed in different industries and activities, an issue that must be at the fore front of policy design and analysis by the government. Common policies may not be helpful in uplifting the youth out of poverty. The findings in Table 9 showing the sectoral location of the youth workers by gender and region shows the same picture as those of Table 8 and the same policy implications hold.

Table 8. Employment by industry (percentage)

\begin{tabular}{|c|c|c|c|c|c|c|c|c|c|}
\hline & \multicolumn{3}{|c|}{ UNHS 2002/2003 } & \multicolumn{3}{|c|}{ UNHS 2005/2006 } & \multicolumn{3}{|c|}{ UNHS 2009/2010 } \\
\hline & $15-24$ & 25-35 & $18-30$ & $15-24$ & 25-35 & $18-30$ & $15-24$ & 25-35 & $18-30$ \\
\hline Agriculture, forestry and fishing & 72.30 & 58.95 & 63.51 & 81.69 & 65.4 & 71.59 & 74.31 & 60.91 & 64.14 \\
\hline Trade & 10.69 & 15.92 & 14.32 & 5.83 & 11.37 & 8.98 & 6.21 & 12.75 & 9.71 \\
\hline Manufacturing & 4.39 & 7.51 & 6.21 & 3.44 & 5.28 & 4.5 & 4.87 & 6.45 & 6.38 \\
\hline Transport and communications & 2.38 & 2.86 & 3.12 & 1.56 & 3.14 & 2.85 & 1.84 & 3.37 & 3.15 \\
\hline Hotels, restaurants, bars & 2.29 & 3.16 & 2.92 & 1.38 & 2.02 & 1.91 & 2.6 & 2.16 & 3.14 \\
\hline Private households & 2.47 & 1.86 & 1.95 & 1.59 & 0.66 & 1.08 & 2.06 & 0.87 & 1.57 \\
\hline Education & 1.43 & 0.93 & 0.49 & 0.9 & 4.21 & 2.57 & 1.88 & 3.86 & 3.51 \\
\hline Others & 4.06 & 8.81 & 7.48 & 3.59 & 7.85 & 6.53 & 6.23 & 9.63 & 8.4 \\
\hline Total & 100 & 100 & 100 & 100 & 100 & 100 & 100 & 100 & 100 \\
\hline \multicolumn{10}{|l|}{ Male } \\
\hline Agriculture, forestry and fishing & 68.33 & 48.38 & 53.84 & 78.42 & 56.73 & 64.66 & 73.36 & 53.46 & 58.68 \\
\hline Trade & 12.8 & 19.91 & 17.99 & 6.77 & 12.48 & 9.88 & 6.29 & 13.62 & 10.45 \\
\hline Manufacturing & 5.11 & 9.03 & 7.72 & 5.27 & 6.87 & 6.25 & 5.58 & 8.83 & 8.85 \\
\hline Transport and communications & 4.67 & 5.64 & 6.49 & 2.81 & 6.09 & 5.7 & 4.02 & 6.59 & 6.8 \\
\hline Hotels, restaurants, bars & 0.79 & 1.72 & 1.39 & 0.45 & 0.66 & 0.52 & 1.77 & 0.58 & 1.7 \\
\hline Private households & 1.22 & 0.57 & 0.97 & 0.79 & 0.33 & 0.62 & 0.54 & 0.47 & 0.44 \\
\hline Education & 1.85 & 4.7 & 3.56 & 0.73 & 4.95 & 2.89 & 0.92 & 3.2 & 2.44 \\
\hline Others & 5.23 & 10.04 & 8.04 & 4.76 & 11.89 & 9.48 & 7.52 & 13.24 & 10.64 \\
\hline Total & 100 & 100 & 100 & 100 & 100 & 100 & 100 & 100 & 100 \\
\hline \multicolumn{10}{|l|}{ Female } \\
\hline Agriculture, forestry and fishing & 75.71 & 69.14 & 71.49 & 84.69 & 73.88 & 77.64 & 74.90 & 68.51 & 68.69 \\
\hline Trade & 9.23 & 11.72 & 11.26 & 4.96 & 10.27 & 8.19 & 6.21 & 11.51 & 9.09 \\
\hline Manufacturing & 3.71 & 6.22 & 4.96 & 1.76 & 3.73 & 2.97 & 4.32 & 4.63 & 4.59 \\
\hline Transport and communications & 0.36 & 0.21 & 0.37 & 0.42 & 0.26 & 0.35 & 0.00 & 0.21 & 0.04 \\
\hline Hotels, restaurants, bars & 3.43 & 4.56 & 4.16 & 2.24 & 3.35 & 3.11 & 3.36 & 3.73 & 4.38 \\
\hline Private households & 3.51 & 1.10 & 2.09 & 2.32 & 0.98 & 1.49 & 3.46 & 1.20 & 2.61 \\
\hline Education & 1.14 & 3.79 & 2.45 & 1.06 & 3.48 & 2.28 & 2.64 & 4.48 & 4.32 \\
\hline
\end{tabular}




\begin{tabular}{|c|c|c|c|c|c|c|c|c|c|}
\hline Others & 2.9 & 3.26 & 3.22 & 2.56 & 4.04 & 3.95 & 5.11 & 5.72 & 6.29 \\
\hline Total & 100 & 100 & 100 & 100 & 100 & 100 & 100.00 & 100.00 & 100.00 \\
\hline \multicolumn{10}{|l|}{ Urban } \\
\hline Agriculture, forestry and fishing & 15.15 & 11.35 & 11.52 & 30.22 & 15.94 & 19.97 & 18.24 & 9.36 & 10.78 \\
\hline Trade & 31.43 & 30.69 & 31.09 & 22.94 & 30.84 & 27.97 & 19.47 & 32.74 & 24.76 \\
\hline Manufacturing & 10.88 & 15.61 & 13.54 & 7.58 & 10.04 & 7.69 & 14.83 & 13.38 & 15.02 \\
\hline Transport and communications & 7.49 & 7.18 & 8.53 & 4.94 & 7.92 & 7.62 & 4.55 & 5.66 & 5.6 \\
\hline Hotels, restaurants, bars & 6.81 & 7.22 & 8.31 & 6.56 & 5.65 & 5.99 & 11.56 & 4.12 & 9.52 \\
\hline Private households & 12.3 & 3.42 & 7.16 & 7.83 & 2.25 & 4.28 & 9.25 & 1.8 & 5.63 \\
\hline Education & 2.84 & 5.32 & 3.76 & 3.19 & 5.79 & 5.11 & 2.72 & 7.2 & 6.02 \\
\hline Others & 13.09 & 19.21 & 16.09 & 16.75 & 21.57 & 21.37 & 19.37 & 25.76 & 22.68 \\
\hline Total & 100 & 100 & 100 & 100 & 100 & 100 & 100 & 100 & 100 \\
\hline \multicolumn{10}{|l|}{ Rural } \\
\hline Agriculture, forestry and fishing & 81.34 & 68.46 & 73.52 & 88.68 & 76.59 & 81.44 & 84.92 & 73.11 & 76.77 \\
\hline Trade & 7.62 & 12.74 & 11.07 & 3.5 & 6.96 & 5.36 & 3.71 & 7.84 & 6.14 \\
\hline Manufacturing & 3.32 & 6.00 & 4.79 & 2.88 & 4.21 & 3.89 & 2.99 & 5.17 & 4.52 \\
\hline Transport and communications & 1.54 & 2.00 & 2.09 & 1.1 & 2.06 & 1.94 & 1.29 & 2.86 & 2.55 \\
\hline Hotels, restaurants, bars & 1.49 & 2.37 & 1.88 & 0.68 & 1.2 & 1.13 & 0.93 & 1.7 & 1.65 \\
\hline Private households & 0.89 & 0.33 & 0.52 & 0.74 & 0.3 & 0.47 & 0.77 & 0.61 & 0.66 \\
\hline Education & 1.25 & 4.02 & 2.79 & 0.59 & 3.85 & 2.08 & 1.7 & 3.05 & 2.85 \\
\hline Others & 2.54 & 4.07 & 3.34 & 1.83 & 4.84 & 3.7 & 3.68 & 5.66 & 4.86 \\
\hline Total & 100 & 100 & 100 & 100 & 100 & 100 & 100 & 100 & 100 \\
\hline \multicolumn{10}{|l|}{ Kampala } \\
\hline Agriculture, forestry and fishing & 5.16 & 3.1 & 2.65 & 1.17 & 3.66 & 2.2 & 8.93 & 0.64 & 3.01 \\
\hline Trade & 37.71 & 28.33 & 31.55 & 32.6 & 38.3 & 35.96 & 20.45 & 34.43 & 26.1 \\
\hline Manufacturing & 9.12 & 20.08 & 14.57 & 11.46 & 10.66 & 9.09 & 20.44 & 12.91 & 17.35 \\
\hline Transport and communications & 9.26 & 7.33 & 9.22 & 6.25 & 8.94 & 8.92 & 4.37 & 10.05 & 7.37 \\
\hline Hotels, restaurants, bars & 6.75 & 10.01 & 11.03 & 9.99 & 7.71 & 7.49 & 6.72 & 4.62 & 6.28 \\
\hline Private households & 17.67 & 5.33 & 10.72 & 11.65 & 3.15 & 5.69 & 8.75 & 4.21 & 6.61 \\
\hline Education & 2.85 & 4.21 & 2.98 & 5.59 & 3.7 & 4.42 & 3.41 & 4.3 & 4.15 \\
\hline Others & 11.48 & 21.61 & 17.29 & 21.28 & 23.88 & 26.23 & 26.93 & 28.83 & 29.14 \\
\hline Total & 100 & 100 & 100 & 100 & 100 & 100 & 100 & 100 & 100 \\
\hline \multicolumn{10}{|l|}{ Central } \\
\hline Agriculture, forestry and fishing & 68.67 & 57.92 & 60.5 & 75.41 & 57.73 & 62.75 & 59.38 & 47.62 & 49.33 \\
\hline Trade & 12.65 & 16.28 & 16.21 & 6.84 & 12.8 & 10.52 & 10.13 & 16.67 & 13.11 \\
\hline Manufacturing & 5.17 & 7.08 & 6.56 & 5.48 & 6.72 & 6.32 & 4.55 & 9.06 & 7.87 \\
\hline Transport and communications & 1.87 & 3.35 & 3.2 & 2.23 & 3.89 & 3.94 & 2.77 & 6.23 & 4.91 \\
\hline Hotels, restaurants, bars & 2.77 & 3.07 & 3.11 & 1.94 & 2.8 & 2.93 & 6.48 & 2.85 & 5.91 \\
\hline Private households & 1.81 & 0.94 & 1.4 & 1.69 & 0.7 & 1.24 & 4.55 & 0.75 & 2.94 \\
\hline Education & 1.69 & 4.23 & 2.95 & 1.2 & 4.52 & 3.13 & 2.67 & 6.51 & 5.15 \\
\hline Others & 5.37 & 7.12 & 6.07 & 5.21 & 10.83 & 9.16 & 9.48 & 10.32 & 10.79 \\
\hline Total & 100 & 100 & 100 & 100 & 100 & 100 & 100 & 100 & 100 \\
\hline Eastern & & & & & & & & & \\
\hline
\end{tabular}




\begin{tabular}{|c|c|c|c|c|c|c|c|c|c|}
\hline Agriculture, forestry and fishing & 80.45 & 70.06 & 74.34 & 89.69 & 77.63 & 82.42 & 86.65 & 74.53 & 79.05 \\
\hline Trade & 7.81 & 11.42 & 9.77 & 3.35 & 7.24 & 5.52 & 3.95 & 6.91 & 5.62 \\
\hline Manufacturing & 3.75 & 5.23 & 4.64 & 1.44 & 2.71 & 1.94 & 1.87 & 4.98 & 3.14 \\
\hline Transport and communications & 2.21 & 3.54 & 3.37 & 1.54 & 2.51 & 2.45 & 1.32 & 2.55 & 2.52 \\
\hline Hotels, restaurants, bars & 1.71 & 2.35 & 1.72 & 0.82 & 0.69 & 1.09 & 0.16 & 2.86 & 2.05 \\
\hline Private households & 0.28 & 0.12 & 0.15 & 0.54 & 0.16 & 0.25 & 1.11 & 0.67 & 1.05 \\
\hline Education & 1.12 & 3.2 & 2.36 & 0.79 & 4.92 & 2.86 & 1.27 & 1.75 & 2.01 \\
\hline Others & 2.68 & 4.07 & 3.65 & 1.82 & 4.15 & 3.47 & 3.68 & 5.74 & 4.57 \\
\hline Total & 100 & 100 & 100 & 100 & 100 & 100 & 100 & 100 & 100 \\
\hline \multicolumn{10}{|l|}{ Northern } \\
\hline Agriculture, forestry and fishing & 84.04 & 65.35 & 73.26 & 86.92 & 74.51 & 79.47 & 83.77 & 74.49 & 76.69 \\
\hline Trade & 4.75 & 13.46 & 10.07 & 4.75 & 6.89 & 6.14 & 4.74 & 6.46 & 6.38 \\
\hline Manufacturing & 4.88 & 9.78 & 7.59 & 3.79 & 6.16 & 5.43 & 6.83 & 7.39 & 8.57 \\
\hline Transport and communications & 1.2 & 1.05 & 1.42 & 0.83 & 1.95 & 1.68 & 0.81 & 0.31 & 0.94 \\
\hline Hotels, restaurants, bars & 0.95 & 1.99 & 1.28 & 0.58 & 1.25 & 0.96 & 0.49 & 0.6 & 0.65 \\
\hline Private households & 0.71 & 0.26 & 0.36 & 0.47 & 0.52 & 0.34 & 0.17 & 0.49 & 0.3 \\
\hline Education & 1.11 & 3.49 & 2.73 & 0.17 & 2.92 & 1.32 & 0.41 & 3.77 & 2.25 \\
\hline Others & 2.37 & 4.62 & 3.28 & 2.5 & 5.79 & 4.65 & 2.79 & 6.49 & 4.22 \\
\hline Total & 100 & 100 & 100 & 100 & 100 & 100 & 100 & 100 & 100 \\
\hline \multicolumn{10}{|l|}{ Western } \\
\hline Agriculture, forestry and fishing & 74.6 & 60.87 & 66.45 & 88.37 & 74.24 & 81.01 & & 65.17 & 70.39 \\
\hline Trade & 10.39 & 17.25 & 14.84 & 3.93 & 8.54 & 6.16 & 3.48 & 13.25 & 8.57 \\
\hline Manufacturing & 2.82 & 5.37 & 4.23 & 2.13 & 3.94 & 3.38 & 3.68 & 4.54 & 4.66 \\
\hline Transport and communications & 2.22 & 1.75 & 2.24 & 0.81 & 2.09 & 1.62 & 1.72 & 2.15 & 2.44 \\
\hline Hotels, restaurants, bars & 2.02 & 2.91 & 2.69 & 0.66 & 1.25 & 1.05 & 2.70 & 1.22 & 2.58 \\
\hline Private households & 3.04 & 0.58 & 1.39 & 1.61 & 0.39 & 1.06 & 1.19 & 0.44 & 0.55 \\
\hline Education & 1.53 & 5.71 & 3.63 & 0.51 & 4.38 & 2.24 & 2.51 & 3.68 & 3.96 \\
\hline Others & 3.37 & 5.56 & 4.53 & 1.98 & 5.18 & 3.49 & 4.14 & 9.56 & 6.85 \\
\hline Total & 100 & 100 & 100 & 100 & 100 & 100 & 100 & 100 & 100 \\
\hline
\end{tabular}

Source: Various rounds of the UNHS; 2002/03, 2005/06 and 2009/10

Table 9. Employment by the major sectors (percentage)

\begin{tabular}{|c|c|c|c|c|c|c|c|c|c|}
\hline & \multicolumn{3}{|c|}{ UNHS $2002 / 2003$} & \multicolumn{3}{|c|}{ UNHS 2005/2006 } & \multicolumn{3}{|c|}{ UNHS 2009/2010 } \\
\hline & $15-24$ & $25-35$ & $18-30$ & $15-24$ & $25-35$ & $18-30$ & $15-24$ & $25-35$ & $18-30$ \\
\hline Primary & 72.41 & 58.95 & 63.58 & 81.69 & 65.4 & 71.59 & 74.31 & 60.91 & 64.14 \\
\hline Manufacturing/production & 5.57 & 9.8 & 8.01 & 4.67 & 7.82 & 6.64 & 7.07 & 10.04 & 9.24 \\
\hline Services & 22.02 & 31.25 & 28.41 & 13.65 & 26.78 & 21.77 & 18.62 & 29.05 & 26.62 \\
\hline Total & 100 & 100 & 100 & 100 & 100 & 100 & 100 & 100 & 100 \\
\hline \multicolumn{10}{|l|}{ Male } \\
\hline Primary & 68.34 & 48.39 & 53.85 & 78.42 & 56.73 & 64.66 & 73.36 & 53.46 & 58.68 \\
\hline Manufacturing/production & 7.52 & 13.38 & 11.46 & 7.74 & 11.79 & 10.66 & 10.12 & 15.59 & 14.56 \\
\hline Services & 24.14 & 38.24 & 34.69 & 13.83 & 31.49 & 24.67 & 16.53 & 30.95 & 26.76 \\
\hline Total & 100 & 100 & 100 & 100 & 100 & 100 & 100 & 100 & 100 \\
\hline
\end{tabular}




\begin{tabular}{|c|c|c|c|c|c|c|c|c|c|}
\hline \multicolumn{10}{|l|}{ Female } \\
\hline Primary & 75.90 & 69.14 & 71.61 & 84.69 & 73.88 & 77.64 & 74.9 & 68.51 & 68.69 \\
\hline Manufacturing/production & 3.79 & 6.54 & 5.17 & 1.83 & 3.95 & 3.13 & 4.53 & 4.95 & 4.96 \\
\hline Services & 20.31 & 24.32 & 23.23 & 13.47 & 22.17 & 19.23 & 20.57 & 26.53 & 26.35 \\
\hline Total & 100 & 100 & 100 & 100 & 100 & 100 & 100 & 100 & 100 \\
\hline \multicolumn{10}{|l|}{ Urban } \\
\hline Primary & 15.32 & 11.35 & 11.59 & 30.22 & 15.94 & 19.97 & 18.24 & 9.36 & 10.78 \\
\hline Manufacturing/production & 14.48 & 20.6 & 18.2 & 12.78 & 15.04 & 13.24 & 19.3 & 19.31 & 20.29 \\
\hline Services & 70.2 & 68.05 & 70.2 & 57.00 & 69.03 & 66.78 & 62.47 & 71.33 & 68.92 \\
\hline Total & 100 & 100 & 100 & 100 & 100 & 100 & 100 & 100 & 100 \\
\hline \multicolumn{10}{|l|}{ Rural } \\
\hline Primary & 81.34 & 68.46 & 73.52 & 88.68 & 76.59 & 81.44 & 84.92 & 73.11 & 76.77 \\
\hline Manufacturing/production & 4.11 & 7.75 & 6.06 & 3.56 & 6.19 & 5.38 & 4.71 & 8.14 & 6.75 \\
\hline Services & 14.55 & 23.79 & 20.42 & 7.75 & 17.22 & 13.18 & 10.37 & 18.75 & 16.48 \\
\hline Total & 100 & 100 & 100 & 100 & 100 & 100 & 100 & 100 & 100 \\
\hline \multicolumn{10}{|l|}{ Kampala } \\
\hline Primary & 5.29 & 3.1 & 2.68 & 1.17 & 3.66 & 2.2 & 8.93 & 0.64 & 3.01 \\
\hline Manufacturing/production & 11.53 & 25.69 & 19.15 & 17.03 & 14.59 & 14.75 & 26.87 & 18.05 & 23.55 \\
\hline Services & 83.19 & 71.21 & 78.17 & 81.8 & 81.75 & 83.05 & 64.19 & 81.31 & 73.44 \\
\hline Total & 100 & 100 & 100 & 100 & 100 & 100 & 100 & 100 & 100 \\
\hline \multicolumn{10}{|l|}{ Central } \\
\hline Primary & 68.67 & 57.92 & 60.5 & 75.41 & 57.73 & 62.75 & 59.38 & 47.62 & 49.33 \\
\hline Manufacturing/production & 7.06 & 9.64 & 8.89 & 7.46 & 10.4 & 9.78 & 7.9 & 12.73 & 11.56 \\
\hline Services & 24.28 & 32.43 & 30.61 & 17.13 & 31.87 & 27.47 & 32.72 & 39.65 & 39.11 \\
\hline Total & 100 & 100 & 100 & 100 & 100 & 100 & 100 & 100 & 100 \\
\hline Primary & 80.45 & 70.07 & 74.35 & 89.69 & 77.63 & 82.42 & 86.65 & 74.53 & 79.05 \\
\hline Manufacturing/production & 4.58 & 5.99 & 5.55 & 2.1 & 4.19 & 3.27 & 4.01 & 7.85 & 5.43 \\
\hline Services & 14.98 & 23.94 & 20.10 & 8.21 & 18.18 & 14.31 & 9.34 & 17.62 & 15.52 \\
\hline Total & 100 & 100 & 100 & 100 & 100 & 100 & 100 & 100 & 100 \\
\hline \multicolumn{10}{|l|}{ Northern } \\
\hline Primary & 84.07 & 65.37 & 73.29 & 86.92 & 74.51 & 79.47 & 83.77 & 74.49 & 76.69 \\
\hline Manufacturing/production & 5.51 & 12.29 & 9.05 & 4.79 & 9.32 & 7.49 & 7.82 & 11.01 & 9.77 \\
\hline Services & 10.42 & 22.34 & 17.66 & 8.29 & 16.17 & 13.04 & 8.41 & 14.51 & 13.54 \\
\hline Total & 100 & 100 & 100 & 100 & 100 & 100 & 100 & 100 & 100 \\
\hline \multicolumn{10}{|l|}{ Western } \\
\hline Primary & 74.60 & 60.87 & 66.45 & 88.37 & 74.24 & 81.01 & 80.58 & 65.17 & 70.39 \\
\hline Manufacturing/production & 3.73 & 7.79 & 5.93 & 2.74 & 5.49 & 4.32 & 4.81 & 8.18 & 7.34 \\
\hline Services & 21.66 & 31.34 & 27.63 & 8.89 & 20.27 & 14.67 & 14.61 & 26.65 & 22.27 \\
\hline Total & 100 & 100 & 100 & 100 & 100 & 100 & 100 & 100 & 100 \\
\hline
\end{tabular}

Source: Various rounds of the UNHS; 2002/03, 2005/06 and 2009/10

Table 10. GDP by economic activity at constant (2002) prices, percentage share, calendar years

\begin{tabular}{lllllllll}
\hline Activity & 2004 & 2005 & 2006 & 2007 & 2008 & 2009 & 2010 & 2011 \\
\hline
\end{tabular}




\begin{tabular}{lcccccccc}
\hline Agriculture & 21 & 19 & 18 & 17 & 15 & 15 & 15 & 14 \\
Industry & 23 & 25 & 25 & 25 & 26 & 25 & 25 & 26 \\
Manufacturing & 7 & 7 & 7 & 7 & 7 & 7 & 7 & 7 \\
Construction & 12 & 14 & 14 & 14 & 16 & 15 & 15 & 16 \\
Services & 50 & 50 & 50 & 50 & 50 & 51 & 52 & 52 \\
Adjustments & 6 & 6 & 7 & 8 & 9 & 9 & 8 & 8 \\
\hline
\end{tabular}

Source: Background to the budget, various series

Considering the occupational distribution of the youth labor force in table 11 reveals pretty the same picture as in tables 8 and 9. It is revealed that the youth with occupations in agriculture accounted for the largest single proportion of the total employment for the period 2002-2010. In 2002/03, 69\% of the youth $15-24$ years had occupations in agriculture, the percentage increased in $2005 / 06$ to $78 \%$ before declining to $70 \%$ in $2009 / 10$. The youth workers with professional occupations witnessed a declining trend over the period 2002-2010. In 2002/03, $0.2 \%$ of the youth had professional occupations, the percentage declined to $0.14 \%$ in $2005 / 06$ before rising slightly to $0.36 \%$ in 2009/10 (Table 11). The service sector which contributes most to GDP as shown in table 10 still trails with limited absorption of the youth workforce. In 2002/03, $13 \%$ of the youth workers had occupations in the service sector, the percentage declined to $7 \%$ in 2005/06 before increasing to $10 \%$ in 2009/10. Given that the services sector is a major driver of economic growth in Uganda, one would expect a proportionate creation of jobs in the services sector for the profile of growth to be inclusive through job creation. Therefore, given the distribution of employment in Uganda, it's clear that over the period 2002-2010, Uganda experienced a jobless growth profile. Whereas there was a sectoral shift in GDP composition, this was not accompanied with a sectoral shift in employment, having the majority of the youth concentrated in agriculture whose contribution to GDP is less than $15 \%$. Overall, the youth $15-24$ years having occupations as managers, professionals and technicians together accounted, on average, for less 4 percent and the proportion has not changed significantly since 2002/03.

Considering the gender dimension, it's surprising to observe that there more female youth (15-24 years) employed as professionals compared to their male counterparts (table 11). However, it is noteworthy that the percentage of both male and female youth employed as professionals is on average less than $1 \%$. Almost a similar picture can be observed for technicians and associate professionals. There is a higher proportion of the female youth (15-24 years) employed as service workers compared to their male counterparts for the entire period under review. Just as we noted before, there is a higher proportion of the female youth employed in agriculture and fisheries compared to their male counterparts. Whereas the majority of the youth irrespective of gender are employed in agriculture, policy must be informed with the fact that females dominate the sector compared to males. On the contrary there is a higher percentage of male youth employed as craft workers, plant and machine operators and in elementary occupations compared to their female counterparts for the entire period under review. Considering location of the youth, there are more youth in the urban area employed as professionals, associate professionals and technicians, service workers, craft workers, plant and machine operators and elementary occupations compared to their rural counterparts. On the contrary, there are more youth workers employed in agriculture in the rural compared to the urban area (table 11). Therefore, government policy analysis needs to consider the different occupational orientations and location peculiarities of the youth for appropriate policy analysis. Considering the regional distribution, there is a higher proportion of the youth in Kampala employed as professionals, associate professionals and technicians, service workers, craft workers, plant and machine operators and elementary occupations compared to other regions of the country. On the other hand, there is a higher proportion of the youth employed in Agriculture in other regions of the country compared to Kampala. Considering Kampala, the greatest concentration of the youth is in the service sector followed by elementary occupations. On the other hand, for the case of other regions, the greatest concentration of the youth is in agriculture. Knowing these differences can be very instrumental in guiding government policy analysis.

The policy implication that emerges from the analysis of occupational distribution of the youth is to improve agricultural productivity where the majority of the youth are located. Additionally, there is need to design policies intended to impart professional and technical skills to the youth so that they are equipped to participate more in professional and technical occupations.

Table 11. Youth occupational distribution (percentage) 


\begin{tabular}{|c|c|c|c|c|c|c|c|c|c|}
\hline & \multicolumn{3}{|c|}{ UNHS 2002/2003 } & \multicolumn{3}{|c|}{ UNHS 2005/2006 } & \multicolumn{3}{|c|}{ UNHS 2009/2010 } \\
\hline & $15-24$ & $25-35$ & $18-30$ & $15-24$ & $25-35$ & $18-30$ & $15-24$ & 25-35 & $18-30$ \\
\hline Professionals & 0.16 & 1.07 & 0.51 & 0.14 & 1.19 & 0.53 & 0.36 & 2.49 & 1.43 \\
\hline Technicians and associate professionals & 0.81 & 1.85 & 1.37 & 1.13 & 4.77 & 3.04 & 1.83 & 4.85 & 3.99 \\
\hline Service workers & 13.13 & 19.76 & 17.73 & 7.11 & 12.5 & 10.8 & 10.05 & 14.95 & 13.35 \\
\hline Agricultural and fishery workers & 69.39 & 56.12 & 60.55 & 77.96 & 60.81 & 66.83 & 69.6 & 56.29 & 58.63 \\
\hline Craft and related workers & 3.22 & 6.6 & 5.16 & 2.48 & 5.96 & 4.11 & 3.76 & 4.88 & 4.79 \\
\hline Plant and machine operators & 1.7 & 4.19 & 3.25 & 1.05 & 3.00 & 2.42 & 0.5 & 1.68 & 1.31 \\
\hline Elementary occupations & 11.45 & 9.82 & 11.01 & 9.77 & 11.03 & 11.65 & 13.33 & 14.18 & 15.79 \\
\hline Others & 0.14 & 0.59 & 0.42 & 0.36 & 0.74 & 0.63 & 0.57 & 0.68 & 0.70 \\
\hline Total & 100 & 100 & 100 & 100 & 100 & 100 & 100 & 100 & 100 \\
\hline \multicolumn{10}{|l|}{ Male } \\
\hline Professionals & 0.15 & 1.49 & 0.69 & 0.11 & 1.75 & 0.7 & 0.08 & 2.63 & 1.61 \\
\hline Technicians and associate professionals & 0.42 & 2.24 & 1.3 & 0.91 & 5.44 & 3.4 & 1.47 & 5.76 & 4.05 \\
\hline Service workers & 12.75 & 21.2 & 18.76 & 6.41 & 10.97 & 9.42 & 9.01 & 13.88 & 12.26 \\
\hline Agricultural and fishery workers & 63.31 & 44.09 & 48.69 & 72.37 & 50.48 & 57.24 & 67.25 & 46.2 & 50.71 \\
\hline Craft and related workers & 4.32 & 9.24 & 7.58 & 3.66 & 8.77 & 6.14 & 5.19 & 7.99 & 7.62 \\
\hline Plant and machine operators & 2.29 & 5.46 & 4.61 & 2.15 & 6.01 & 5.16 & 1.1 & 3.13 & 2.71 \\
\hline Elementary occupations & 16.56 & 16 & 17.94 & 14.17 & 15.74 & 17.52 & 15.62 & 19.78 & 20.66 \\
\hline Others & 0.2 & 0.58 & 0.43 & 0.22 & 0.84 & 0.4 & 0.28 & 0.63 & 0.38 \\
\hline Total & 100 & 100 & 100 & 100 & 100 & 100 & 100 & 100 & 100 \\
\hline \multicolumn{10}{|l|}{ Female } \\
\hline Professionals & 0.19 & 0.67 & 0.38 & 0.16 & 0.65 & 0.38 & 0.60 & 2.55 & 1.32 \\
\hline Technicians and associate professionals & 1.13 & 1.45 & 1.36 & 1.34 & 4.11 & 2.72 & 2.09 & 3.86 & 3.83 \\
\hline Service workers & 13.74 & 17.99 & 16.86 & 7.76 & 14.01 & 12 & 10.88 & 15.74 & 14.32 \\
\hline Agricultural and fishery workers & 74.51 & 67.88 & 70.33 & 83.09 & 70.92 & 75.19 & 71.33 & 66.51 & 65.16 \\
\hline Craft and related workers & 2.23 & 4.18 & 3.16 & 1.4 & 3.21 & 2.33 & 2.43 & 1.93 & 2.42 \\
\hline Plant and machine operators & 1.12 & 3.17 & 2.22 & 0.05 & 0.05 & 0.04 & 0.00 & 0.14 & 0.09 \\
\hline Elementary occupations & 6.91 & 4.09 & 5.25 & 5.72 & 6.42 & 6.53 & 11.89 & 8.58 & 11.90 \\
\hline Others & 0.18 & 0.57 & 0.45 & 0.49 & 0.64 & 0.81 & 0.79 & 0.68 & 0.95 \\
\hline Total & 100 & 100 & 100 & 100 & 100 & 100 & 100 & 100 & 100 \\
\hline \multicolumn{10}{|l|}{ Urban } \\
\hline Professionals & 0.97 & 3.06 & 1.61 & 0.9 & 2.74 & 2.15 & 0.34 & 1.31 & 0.93 \\
\hline Technicians and associate professionals & 2.43 & 5.11 & 3.97 & 4.07 & 9.12 & 6.91 & 1.48 & 2.59 & 2.47 \\
\hline Service workers & 36.58 & 40.97 & 40.65 & 30.09 & 32.06 & 32.90 & 5.42 & 10.44 & 8.41 \\
\hline Agricultural and fishery workers & 13.32 & 10.09 & 9.91 & 28.02 & 14.05 & 17.88 & 79.51 & 67.85 & 70.29 \\
\hline Craft and related workers & 8.37 & 13.8 & 11.65 & 7.63 & 13.93 & 9.99 & 3.01 & 4.58 & 4.25 \\
\hline Plant and machine operators & 3.12 & 6.01 & 4.83 & 4.11 & 7.84 & 7.31 & 0.39 & 1.20 & 1.02 \\
\hline Elementary occupations & 34.49 & 18.53 & 25.6 & 22.72 & 17.8 & 20.23 & 9.53 & 11.73 & 12.28 \\
\hline Others & 0.72 & 2.43 & 1.78 & 2.46 & 2.46 & 2.63 & 0.32 & 0.29 & 0.35 \\
\hline Total & 100 & 100 & 100 & 100 & 100 & 100 & 100 & 100 & 100 \\
\hline \multicolumn{10}{|l|}{ Rural } \\
\hline Professionals & 0.05 & 0.68 & 0.31 & 0.03 & 0.84 & 0.22 & 0.51 & 8.03 & 3.65 \\
\hline
\end{tabular}




\begin{tabular}{|c|c|c|c|c|c|c|c|c|c|}
\hline Technicians and associate professionals & 0.54 & 1.18 & 0.83 & 0.74 & 3.78 & 2.3 & 3.54 & 14.22 & 10.08 \\
\hline Service workers & 9.6 & 15.3 & 13.33 & 3.99 & 8.08 & 6.58 & 34.18 & 33.36 & 34.30 \\
\hline Agricultural and fishery workers & 78.18 & 65.43 & 70.29 & 84.74 & 71.4 & 76.16 & 17.06 & 7.57 & 9.09 \\
\hline Craft and related workers & 2.38 & 5.23 & 3.90 & 1.79 & 4.15 & 2.99 & 7.16 & 6.57 & 7.13 \\
\hline Plant and machine operators & 1.43 & 3.95 & 3.00 & 0.64 & 1.9 & 1.49 & 1.05 & 3.50 & 2.42 \\
\hline Elementary occupations & 7.72 & 8.03 & 8.16 & 8.01 & 9.5 & 10.02 & 34.73 & 24.55 & 31.22 \\
\hline Others & 0.11 & 0.21 & 0.19 & 0.07 & 0.35 & 0.24 & 1.78 & 2.21 & 2.12 \\
\hline Total & 100 & 100 & 100 & 100 & 100 & 100 & 100 & 100 & 100 \\
\hline \multicolumn{10}{|l|}{ Kampala } \\
\hline Professionals & 1.33 & 3.87 & 2.1 & 2.57 & 1.97 & 2.32 & 1.46 & 9.48 & 5.36 \\
\hline Technicians and associate professionals & 2.79 & 5.17 & 4.39 & 6.09 & 7.49 & 6.07 & 4.98 & 6.40 & 6.42 \\
\hline Service workers & 41.37 & 42.40 & 44.35 & 41.66 & 35.55 & 40.34 & 29.40 & 36.05 & 33.02 \\
\hline Agricultural and fishery workers & 2.98 & 2.64 & 1.25 & 0.86 & 2.18 & 0.61 & 8.60 & 0.00 & 2.34 \\
\hline Craft and related workers & 5.07 & 16.09 & 10.93 & 10.05 & 17.03 & 12.25 & 7.40 & 9.14 & 9.06 \\
\hline Plant and machine operators & 2.85 & 4.82 & 4.28 & 3.17 & 9.2 & 8.05 & 1.99 & 4.84 & 3.23 \\
\hline Elementary occupations & 42.94 & 22.08 & 30.11 & 30.06 & 23.11 & 26.02 & 43.52 & 31.22 & 37.62 \\
\hline Others & 0.67 & 2.92 & 2.59 & 5.54 & 3.48 & 4.32 & 2.65 & 2.86 & 2.95 \\
\hline Total & 100 & 100 & 100 & 100 & 100 & 100 & 100 & 100 & 100 \\
\hline \multicolumn{10}{|l|}{ Central } \\
\hline Professionals & 0.2 & 0.86 & 0.29 & 0.12 & 1.7 & 0.90 & 0.00 & 4.25 & 1.68 \\
\hline Technicians and associate professionals & 1.0 & 2.24 & 1.65 & 1.2 & 5.44 & 3.69 & 2.66 & 8.60 & 6.55 \\
\hline Service workers & 15.3 & 20.4 & 19.57 & 9.84 & 16.67 & 14.80 & 20.36 & 18.14 & 20.82 \\
\hline Agricultural and fishery workers & 64.9 & 54.26 & 56.39 & 70.38 & 51.97 & 56.42 & 54.11 & 41.78 & 43.25 \\
\hline Craft and related workers & 5.0 & 5.86 & 5.9 & 3.84 & 6.94 & 5.37 & 3.60 & 5.03 & 5.00 \\
\hline Plant and machine operators & 1.9 & 4.36 & 3.41 & 1.15 & 3.71 & 3.00 & 0.60 & 3.45 & 2.58 \\
\hline Elementary occupations & 11.5 & 11.54 & 12.49 & 13.29 & 13.26 & 15.53 & 17.38 & 18.01 & 18.73 \\
\hline Others & 0.2 & 0.46 & 0.30 & 0.18 & 0.33 & 0.28 & 1.30 & 0.74 & 1.39 \\
\hline Total & 100 & 100 & 100 & 100 & 100 & 100 & 100 & 100 & 100 \\
\hline \multicolumn{10}{|l|}{ Eastern } \\
\hline Professionals & 0.04 & 0.42 & 0.26 & 0.00 & 0.52 & 0.16 & 0.00 & 0.81 & 0.41 \\
\hline Technicians and associate professionals & 0.68 & 1.09 & 0.9 & 1.15 & 5.21 & 3.2 & 1.66 & 2.43 & 2.45 \\
\hline Service workers & 10.16 & 14.58 & 12.44 & 3.95 & 7.13 & 6.17 & 4.46 & 10.38 & 7.70 \\
\hline Agricultural and fishery workers & 78.15 & 68.19 & 71.89 & 88.59 & 76.24 & 81 & 82.94 & 72.14 & 75.52 \\
\hline Craft and related workers & 1.55 & 3.79 & 2.92 & 0.77 & 3.42 & 1.86 & 2.32 & 3.93 & 2.72 \\
\hline Plant and machine operators & 1.04 & 3.44 & 2.4 & 1.21 & 2.53 & 2.25 & 0.43 & 0.96 & 0.75 \\
\hline Elementary occupations & 8.33 & 7.88 & 8.88 & 4.22 & 4.74 & 5.12 & 8.06 & 8.95 & 10.30 \\
\hline Others & 0.07 & 0.61 & 0.32 & 0.12 & 0.22 & 0.24 & 0.13 & 0.40 & 0.16 \\
\hline Total & 100 & 100 & 100 & 100 & 100 & 100 & 100 & 100 & 100 \\
\hline \multicolumn{10}{|l|}{ Northern } \\
\hline Professionals & 0.01 & 0.27 & 0.19 & 0.00 & 0.45 & 0.16 & 0.50 & 2.66 & 1.63 \\
\hline Technicians and associate professionals & 0.16 & 1.5 & 0.62 & 0.31 & 3.39 & 1.72 & 0.17 & 2.89 & 1.50 \\
\hline Service workers & 6.48 & 15.32 & 12.13 & 4.57 & 8.66 & 7.25 & 5.05 & 6.85 & 6.86 \\
\hline Agricultural and fishery workers & 81.6 & 62.52 & 70.62 & 82.95 & 68.27 & 74.04 & 81.47 & 70.95 & 72.95 \\
\hline
\end{tabular}




\begin{tabular}{lrrrrrrrrr}
\hline Craft and related workers & 3.06 & 9.52 & 6.41 & 2.82 & 5.51 & 4.46 & 4.78 & 4.51 & 6.00 \\
Plant and machine operators & 1.18 & 3.92 & 3.05 & 0.89 & 1.75 & 1.64 & 0.00 & 0.26 & 0.19 \\
Elementary occupations & 7.23 & 6.59 & 6.66 & 8.47 & 11.48 & 10.50 & 7.70 & 11.73 & 10.45 \\
Others & 0.27 & 0.34 & 0.34 & 0.00 & 0.48 & 0.22 & 0.34 & 0.16 & 0.41 \\
Total & 100 & 100 & 100 & 100 & 100 & 100 & 100 & 100 & 100 \\
Western & & & & & & & & & \\
Professionals & 0.14 & 1.61 & 0.73 & 0.00 & 1.64 & 0.34 & 0.72 & 1.20 & 1.16 \\
Technicians and associate professionals & 0.7 & 1.47 & 1.1 & 0.85 & 3.93 & 2.53 & 1.74 & 4.91 & 3.94 \\
Service workers & 12.73 & 19.92 & 17.36 & 4.18 & 9.07 & 6.73 & 6.67 & 16.26 & 11.35 \\
Agricultural and fishery workers & 71.3 & 57.54 & 63.39 & 83.1 & 68.12 & 74.49 & 72.72 & 57.48 & 60.96 \\
Craft and related workers & 2.79 & 5.52 & 4.25 & 1.57 & 4.17 & 2.77 & 3.60 & 5.16 & 4.83 \\
Plant and machine operators & 2.09 & 5.12 & 3.91 & 0.64 & 1.73 & 1.29 & 0.51 & 0.88 & 0.87 \\
Elementary occupations & 10.07 & 8.69 & 9.1 & 9.48 & 10.45 & 11.21 & 13.94 & 13.52 & 16.71 \\
Others & 0.16 & 0.13 & 0.16 & 0.18 & 0.9 & 0.64 & 0.09 & 0.59 & 0.18 \\
Total & 100 & 100 & 100 & 100 & 100 & 100 & 100 & 100 & 100 \\
\hline
\end{tabular}

Source: Various rounds of the UNHS; 2002/03, 2005/06 and 2009/10

\subsection{Unemployment and Underemployment}

\subsubsection{Unemployment}

According to the 1982 ILO Resolution, a person who worked for at least one hour in the reference week is regarded as employed, while a person who was "without work", "available for work", or "actively seeking work" is counted as unemployed. Actively seeking work includes "registering at public or private employment exchanges, direct application to employers, checking at work sites, placing or answering newspaper advertisements and looking for financial resources amongst others (UNHS Report, 2009/10). The unemployment rate measures the number of unemployed persons as a percentage of the labour force (UNHS Report, 2005/06).

The youth (15-24 years) unemployment rate in 2002/03 was 4.3\% higher than an overall employment rate of 3.5\% in the same period (Table 12). The youth unemployment rate declined in 2005/06 to 3.1\% higher than the overall unemployment rate of $1.9 \%$ in the same period. In 2009/10, the youth unemployment rate increased to 3.8 slightly lower than the overall rate $4.2 \%$ in $2009 / 10$ (Table 12). One of the greatest problems is the way UBOS computes the unemployment rates. These reported figures are quite low given that Uganda has increased number of youths graduating out of Universities per year and joining the labour force as unemployed. Whereas some people are doing work, many jobs in the informal sector cannot make one afford a decent living. This loophole in reporting the national figure of the unemployed has created a pseudo picture in the eyes of the policy makers and hence the efforts designed don't match the pace at which the problem is unfolding. Otherwise stated Uganda's problem is no longer unemployment but underemployment especially in the informal sector which has become quite significant. Considering the gender dimension, the female youth (15-24 years) unemployment rate is consistently higher than the male youth unemployment rate for the period 2002-2010. In 2002/03, the female youth unemployment rate was $5.1 \%$ compared to that of their male counterparts of 3.3\%; in 2005/06 the female youth unemployment rate was approximately $4 \%$ compared to $2.5 \%$ of their male counterparts. In 2009/10, the female youth unemployment rate was $4.1 \%$ compared to $3.3 \%$ of their male counterparts.

Unemployment remained predominantly an urban problem as the youth 15-24 years in urban areas are many times more likely to be unemployed compared to their rural counterparts for the period 2005-2010 (Table 12). The youth unemployment rate in urban areas in 2005/06 was $13 \%$ compared to only $2 \%$ of their counterparts in rural areas; the youth unemployment rate in 2009/10 in urban areas was $11 \%$ compared to only $2 \%$ in the rural areas. It is not surprising therefore that Kampala has the highest unemployment rate followed by the central region. The youth unemployment rate in Kampala in 2002/03 was 26\% compared to the lowest of $0.6 \%$ in Northern Uganda. In 2005/06, the youth unemployment rate in Kampala was 18\% compared to the lowest of $1 \%$ in Eastern and Western Uganda. In 2009/10, the youth unemployment rate was 15\% in Kampala, compared to the lowest of $1.7 \%$ in Western Uganda. It's clear that the youth unemployment rate in Kampala has shown a declining trend but it's many times higher than all other regions in the country. Actually, the youth 
unemployment rate in Kampala ought to be higher than what the statistics seem to suggest, but due to the expansion of the informal sector in the city where the youth do petty jobs, Uganda Bureau of Statistics is bound to capturing fewer unemployed youths. It is also revealed that unemployment rate is highest amongst the labour force with at least secondary education compared to those with primary and lower education. In 2002/03, the youth (15-24 years) unemployment rate for those with post secondary education was $12 \%$ compared to $2 \%$ for the youth with no education. Those with secondary education, the unemployment rate is higher (9\%) compared to those with primary education (3\%). In 2005/06, the youth with postsecondary education had unemployment rate of $10 \%$ compared to $1 \%$ of counterparts with no education at all. Those with secondary education, the unemployment rate is higher (6\%) compared to those with primary education (2\%). In 2009/10, the youth with postsecondary education had unemployment rate of $15 \%$ compared to $3 \%$ of counterparts with no education at all. Those with secondary education, the unemployment rate is higher (5\%) compared to those with primary education (3\%). Government policy emphasizing technical education may reduce on the percentage of educated job seekers.

Table 12. Youth unemployment rate by age cohorts, region, and residence (percentage)

\begin{tabular}{|c|c|c|c|c|c|c|c|c|c|c|}
\hline & \multicolumn{2}{|c|}{ UNHS 2002/03 } & \multicolumn{4}{|c|}{ UNHS 2005/06 } & \multicolumn{4}{|c|}{ UNHS 20092/10 } \\
\hline & $15-24$ & $25-35$ & $18-30$ & $15-24$ & $25-35$ & $18-30$ & $14-64$ & $15-24$ & $25-35$ & $18-30$ \\
\hline Male & 3.3 & 2.84 & 3.56 & 2.51 & 1.93 & 2.69 & 2.6 & 3.3 & 2.3 & 3.0 \\
\hline Female & 5.08 & 2.28 & 4.06 & 3.68 & 2.18 & 3.7 & 4.5 & 4.1 & 5.7 & 5.5 \\
\hline Urban & 2.04 & 1.53 & 1.98 & 13.13 & 5.4 & 10.3 & 8.7 & 11.2 & 7.9 & 11.1 \\
\hline Rural & 16.63 & 7.4 & 12.58 & 1.58 & 1.27 & 1.75 & 2.5 & 2.2 & 3.1 & 2.7 \\
\hline Kampala & 25.99 & 8.00 & 16.2 & 17.58 & 6.58 & 12.43 & 10.7 & 14.8 & 8.5 & 14.0 \\
\hline Central & 5.29 & 4.31 & 5.43 & 3.24 & 1.81 & 3.62 & 5.1 & 5.2 & 7.3 & 7.1 \\
\hline Eastern & 2.51 & 1.78 & 2.54 & 1.07 & 0.7 & 1.08 & 2.5 & 2.1 & 2.9 & 2.6 \\
\hline Northern & 0.63 & 0.68 & 0.73 & 5.34 & 3.55 & 4.86 & 3.4 & 3.7 & 3.2 & 3.4 \\
\hline Western & 1.57 & 1.4 & 1.83 & 0.94 & 0.86 & 1.12 & 1.8 & 1.7 & 1.6 & 1.5 \\
\hline No formal schooling & 1.65 & 1.26 & 1.35 & 1.07 & 1.3 & 0.93 & 3.0 & 3.0 & 3.2 & 2.9 \\
\hline Some or completed primary & 2.99 & 1.52 & 2.44 & 2.2 & 1.28 & 2.21 & 2.9 & 2.9 & 3.3 & 3.5 \\
\hline Some or completed secondary & 9.18 & 4.96 & 7.83 & 5.86 & 2.95 & 5.4 & 5.0 & 4.9 & 5.6 & 5.4 \\
\hline Above secondary & 12.42 & 6.02 & 9.78 & 9.77 & 6.72 & 10.56 & 6.4 & 14.5 & 5.7 & 9.1 \\
\hline Total & 4.29 & 2.54 & 3.84 & 3.13 & 2.06 & 3.23 & 3.6 & 3.8 & 4.0 & 4.4 \\
\hline
\end{tabular}

Source: Various rounds of the UNHS; 2002/03, 2005/06 and 2009/10

\subsubsection{Underemployment}

The 'standard' unemployment rate does not provide a real picture of the supply and demand balance of the labor market. It also does not adequately reflect the degree of inefficiency that prevails in the labor market. Alternative indicators such as underemployment rates and work intensity are therefore necessary to supplement the standard 
indicator of unemployment rate in revealing the labor market reality in Uganda (UNHS Report, 2009/10). A person is classified as time-underemployed if she or he has worked less than 40 hours a week and is willing and available to work more hours (UNHS, 2005/06 and 2009/10). We computed the time related underemployment rate for youth in the period 2005/06 and not for 2002/03 and 2009/10 due to the inconsistency in the nature of questions that were asked in these two surveys that could lead to misleading statistics. The questions on the number of hours worked were directed to only the main activity and ignored the secondary activities that the youth labor force were engaged in. In 2005/06, 11\% of the youth 15-24 years worked less than 40 hours a week (Table 13). There are differences in the time related underemployment by gender. $13 \%$ of the male youth $15-24$ years worked less than 40 hours a week compared to only $9 \%$ of their female counterparts. The lower rate of time related female youth underemployment can be accounted for by high participation of females in agriculture and family labor compared to their male counterparts who in most of the cases seek work outside their homes. Considering location, there is a high rate of underemployment in the rural compared to the urban areas. $12 \%$ of youth workers in the rural areas were time underemployed compared to $9 \%$ of their counterparts in the urban areas. Similarly, time underemployment was $10 \%$ in Kampala compared to the highest of $16 \%$ in Central and Northern Uganda. Looking at education attainment in relation to time underemployment, it is revealed that underemployment is highest amongst the youth with low education attainment. Time related underemployment is $11 \%$ for those with no formal schooling compared to $8 \%$ of the youth that attained postsecondary education. It's also $12 \%$ for the youth that had some or completed primary schooling compared to $8 \%$ of counterparts with postsecondary education. It's also $9 \%$ for those with secondary education compared to $8 \%$ of counterparts with postsecondary education (Table 13). These results imply that youth with limited education are involved in activities whose work intensity is so low that it is difficult for them to attain 40 hours of work a week. This is typical of subsistence agriculture where the majority of the youth are located. A similar picture is observed for other definitions of the youth adopted in this study. However, the seemingly low time-related underemployment rate needs to be interpreted with a lot of caution. It might be that the type of underemployment existing in Uganda takes the form of low returns to labor which in turn means working for longer hours or holding multiple jobs in an effort to generate a sufficient income.

Table 13. Youth Time related underemployment rate by age cohorts, region, and residence (percentage)

\begin{tabular}{llll}
\hline & $\mathbf{1 5 - 2 4}$ & $\mathbf{2 5 - 3 5}$ & $\mathbf{1 8 - 3 0}$ \\
\hline Male & 13.17 & 17.04 & 16.70 \\
Female & 9.26 & 11.79 & 10.77 \\
Urban & 8.54 & 9.28 & 9.00 \\
Rural & 11.48 & 15.53 & 14.40 \\
Kampala & 9.93 & 7.45 & 7.85 \\
Central & 15.66 & 17.44 & 17.65 \\
Eastern & 8.18 & 11.55 & 10.71 \\
Northern & 16.12 & 22.65 & 20.25 \\
Western & 7.16 & 10.23 & 9.19 \\
No formal schooling & 11.39 & 14.94 & 12.44 \\
Some or completed primary & 11.98 & 16.28 & 14.97 \\
Some or completed secondary & 8.71 & 9.60 & 10.40 \\
Above secondary & 7.91 & 10.18 & 11.24 \\
Total & $\mathbf{1 1 . 1 3}$ & $\mathbf{1 4 . 3 8}$ & $\mathbf{1 3 . 5 3}$ \\
\hline
\end{tabular}

Source: UNHS 2005/06

Table 14. Youth skill-related underemployment rate by age cohorts, region, and residence (percentage) 
$\begin{array}{llllllllll}15-24 & 25-35 & 18-30 & 15-24 & 25-35 & 18-30 & 14-64 & 15-24 & 25-35 & 18-30\end{array}$

\begin{tabular}{|c|c|c|c|c|c|c|c|c|c|c|}
\hline Male & 2.99 & 8.90 & 7.09 & 1.59 & 5.30 & 3.42 & 7.7 & 1.8 & 9.8 & 5.3 \\
\hline Female & 2.29 & 3.94 & 3.28 & 0.92 & 2.73 & 2.24 & 8.7 & 11.9 & 9.4 & 12.3 \\
\hline Urban & 5.94 & 13.24 & 10.22 & 3.95 & 9.95 & 7.96 & 11.4 & 9.9 & 15.0 & 13.0 \\
\hline Rural & 2.08 & 4.95 & 3.93 & 0.88 & 2.65 & 1.80 & 5.9 & 5.2 & 5.9 & 4.8 \\
\hline Kampala & 5.20 & 14.95 & 10.89 & 5.12 & 14.24 & 12.00 & 18.2 & 16.70 & 25.9 & 20.5 \\
\hline Central & 3.50 & 5.85 & 5.43 & 1.75 & 3.46 & 2.63 & 9.7 & 10.00 & 8.1 & 10.7 \\
\hline Eastern & 1.86 & 4.05 & 3.05 & 0.58 & 2.21 & 1.22 & 2.5 & 0.00 & 2.8 & 2.4 \\
\hline Northern & 1.33 & 3.88 & 3.03 & 0.69 & 2.57 & 1.80 & 12.7 & 7.50 & 20.7 & 13.1 \\
\hline Western & 2.87 & 8.28 & 6.10 & 1.18 & 3.90 & 2.75 & 3.8 & 3.80 & 5.8 & 3.2 \\
\hline No formal schooling & 0.00 & 0.00 & 0.00 & 0.00 & 0.00 & 0.00 & 0.0 & 0.0 & 0.0 & 0.0 \\
\hline Some or completed primary & 0.00 & 0.00 & 0.00 & 0.00 & 0.00 & 0.00 & 0.0 & 0.0 & 0.0 & 0.0 \\
\hline Some or completed secondary & 2.63 & 3.92 & 3.28 & 1.31 & 3.67 & 2.97 & 19.4 & 18.0 & 13.3 & 14.2 \\
\hline Above secondary & 74.65 & 72.41 & 76.33 & 55.39 & 43.56 & 46.25 & 19.0 & 31.9 & 25.0 & 27.6 \\
\hline Total & 2.60 & 6.31 & 4.93 & 1.24 & 3.99 & 2.79 & 8.1 & 7.4 & 9.7 & 8.6 \\
\hline
\end{tabular}

Source: Various rounds of the UNHS; 2002/03, 2005/06 and 2009/10

Skills-related inadequate employment includes employed persons who, during the reference week were not already categorized as time-related underemployed; and whose educational attainment were higher than the educational level required by their current main jobs. Wanting/seeking and available to change current work situation in order to use occupational skills more fully (UNHS Report, 2009/10). In 2002/03, the skill related underemployment for the youth 15-24 years was $3 \%$ before declining to $1.2 \%$ 2005/06 and drastically rose to $7.4 \%$ in 2009/10 (Table 14). By gender, for the period 2002-2005, more males were skill underemployed compared to their female counterparts. In 2002/03, 3\% of male youth were skill underemployed compared to $2 \%$ of their female counterparts and also in 2005/06, $2 \%$ of male youth were skill underemployed compared to only $1 \%$ of their female counterparts. In 2009/10 the picture changes to the contrary where female youth were more skill underemployed compared to their male counterparts. $12 \%$ of the female youth were skill underemployed compared to $2 \%$ of their male counterparts. Imparting the skills amongst the youth that match the demand of employers in the labor market is a challenge the government must seriously take on in order to solve the youth employment predicament. The skill related underemployment is more of an urban phenomenon. In 2002/03, 6\% of youth in the urban areas were skill underemployed compared to only $2 \%$ of their counterparts in the rural areas. In 2005/06, $4 \%$ of the youth in urban area were skill underemployed compared to only $1 \%$ of their counterparts in the rural areas. The situation became worse in the period 2009/10 where $10 \%$ of the youth in the urban areas were skill underemployed compared to $5 \%$ of their counterparts in rural areas (Table 14). Similarly, skill underemployment is highest in Kampala compared to other regions in the country. In 2002/03 and 2005/06, $5 \%$ of the youth in Kampala were skill underemployed compared to the lowest of $1 \%$ in Northern Uganda. In 2009/10, 17\% of the youth in Kampala were skill underemployed compared to the lowest of $0 \%$ in Eastern Uganda. As expected, skill underemployment is more rampant amongst the educated youth once compared to their uneducated counterparts. In 2002/03, $75 \%$ of the youth who have attained postsecondary education were 
skill underemployed compared to only $2 \%$ of their counterparts that have attained only secondary education. The situation improved in the period 2005-2010 where 55\% of the youth that have attained postsecondary education were skill underemployed compared to $1 \%$ of counterparts that have attained only secondary education (2002/03) and $32 \%$ of the youth that have attained postsecondary were skill underemployed compared to $18 \%$ of counterparts that have attained secondary education. A similar picture can be observed once we look at other definitions of the youth considered in this paper. As aforementioned, there is a great need to impart private sector-relevant skills amongst the youth workers in addition to changing the education system of the country from predominantly being theoretical to a more practical orientation.

\section{Informal Sector}

The informal sector is by far the most important employer in Uganda. In Uganda, a total of 1.2 million (21\%) households out of the 6.2 million surveyed, had an informal business (UNHS 2009/10). This included those households undertaking agriculture on a commercial basis where at least 50 percent of the produce was sold. Rural-Urban variations show that the majority of the informal businesses were in the rural areas (87\%). By employment, 3.5 million people were engaged in informal businesses including Non-crop agriculture. Those engaged in Non-Agriculture businesses were 2.1 million, 19 percentage points less than those reported in 2002/03. The reduction in employment in 2009/10 could be explained by the fact that there were more households engaged in commercial agriculture than before because of the 3.5 million employees, 40 percent were engaged in informal commercial agriculture (UNHS, 2009/10). The proportion of paid employees in the informal sector increased from nine percent in 2002/03 to 13 percent in 2009/10. Contrary to the expectation, more males (61\%) than females (29\%) were employed in the informal sector. The majority of employees were working proprietors (52\%) followed by unpaid helpers (33\%). It's is further shown that male employees were more likely to work as casual employees compared to their female counterparts. By industry of employment, female employees dominated except for agriculture and services. The majority of females were engaged in food processing (24\%) followed by trade (21\%) and other manufacturing (16\%) while most males were engaged in Agriculture (52\%) followed by Trade (16\%).

Table 15. Youth Informal employment outside agriculture by age cohorts, region, and residence (percentage)

\begin{tabular}{lllll}
\hline & $\mathbf{1 4 - 6 4}$ & $\mathbf{1 5 - 2 4}$ & $\mathbf{2 5 - 3 5}$ & $\mathbf{1 8 - 3 0}$ \\
\hline Male & 83.33 & 92.37 & 84.06 & 86.72 \\
Female & 87.41 & 93.29 & 82.95 & 86.88 \\
Urban & 82.11 & 95.63 & 75.43 & 84.82 \\
Rural & 87.6 & 90.07 & 90.04 & 88.56 \\
Kampala & 82.68 & 95.06 & 76.76 & 86.4 \\
Central & 85.94 & 92.00 & 86.18 & 87.82 \\
Eastern & 84.49 & 90.2 & 88.77 & 88.49 \\
Northern & 82.64 & 94.11 & 77.41 & 84.05 \\
Western & 88.15 & 93.34 & 84.32 & 85.78 \\
No formal schooling & 97.28 & 99.33 & 93.31 & 95.26 \\
Some or completed primary & 93.66 & 94.97 & 93.44 & 92.21 \\
Some or completed secondary & 88.37 & 94.84 & 86.19 & 91.04 \\
Above secondary & 54.39 & 64.37 & 57.92 & 60.15 \\
Total & $\mathbf{8 5 . 1 2}$ & $\mathbf{9 2 . 8 6}$ & $\mathbf{8 3 . 6 1}$ & $\mathbf{8 6 . 8}$ \\
\hline
\end{tabular}

Source: UNHS 2009/10

Considering the specific case of the youth, 93\% of the youth in Uganda were employed in the informal sector outside Agriculture (Table 15). By gender, slightly more female youth (93\%) were engaged in the informal sector outside agriculture compared to their male counterparts (92\%). More youth in urban areas (96\%) were 
engaged in the informal sector outside agriculture compared to their rural counterparts (90\%). Indeed, more youth in Kampala were engaged in the informal sector outside agriculture compared to other regions of the country. Informality amongst the youth is more concentrated amongst youth with limited or no education. 99\% of the youth with no education were involved in the informal sector compared to $64 \%$ of their counterparts with postsecondary education. Government policy should target to increase productivity in the informal sector where the majority of the youth are found; there is need to establish secure premises where the youth can conduct their trade activities as well as enhancing access to easy and cheap finance that can help them scale-up their businesses.

\section{Conclusions}

This paper undertook a structural analysis of the youth labor force in Uganda by documenting their location in the Ugandan economy by residence, region, sector, and employment status. The data were obtained from the Uganda National Household Surveys 2002/03, 2005/06 and 2009/10. We find that the youth population structure of the country poses a big challenge in an effort to create employment, particularly for the youth. The majority of the youth labor force is located in the rural compared to the urban areas of the country. Whereas we find quite impressive labor force participation rates and the employment population ratio, they do not necessarily reflect more and better employment opportunities because of the high degree of informality where most of the youth are underemployed. Over $90 \%$ of the youth were employed in the informal sector outside agriculture with slightly more female youth than their male counterparts. The quality of the youth labor in terms of education is improving though with lower attainment rates at postsecondary level, however, the quality of the youth labor force is higher in urban than in rural areas. An increase in self-employment is observed which an indication of high rate of job creation is in the informal economy. Consequently, there is a limited participation of the youth in professional and technical occupations and in paid employment. There are also discernible gender differences in the status of employment. There are more female youths self-employed in agriculture compared to their male counterparts for the entire period under study (2002-2010). In 2002/03 61\% of the male youth (15-24 years) were self employed in agriculture compared $75 \%$ of their female counterparts. In 2005/06, 71\% of male youth were self-employed in agriculture compared to $83 \%$ of their female counterparts. In 2009/10, there was a general reduction in the percentage of youth self-employed in agriculture, despite this, the percentage of the female youth $(72 \%)$ was higher than that of the male youth (69\%). It's surprising to observe that there more female youth (15-24 years) employed as professionals compared to their male counterparts. However, it is noteworthy that the percentage of both male and female youth employed as professionals is on average less than $1 \%$. Almost a similar picture can be observed for technicians and associate professionals. Connected to this is the finding that there is a higher proportion of the youth labor force employed in agriculture despite its dismal contribution to GDP. Whereas the country experienced sectoral shifts in GDP composition, with the services and manufacturing sector becoming more important than agriculture, there are no sectoral shifts in employment with agriculture remaining the main employer of the youth labor force. Considering the regional distribution, there is a higher proportion of the youth in Kampala employed as professionals, associate professionals and technicians, service workers, craft workers, plant and machine operators and elementary occupations compared to other regions of the country. On the other hand, there is a higher proportion of the youth employed in Agriculture in other regions of the country compared to Kampala. Considering Kampala, the greatest concentration of the youth is in the service sector followed by elementary occupations. On the other hand, for the case of other regions, the greatest concentration of the youth is in agriculture. Knowing these differences can be very instrumental in guiding government policy analysis. Very low youth unemployment rates are observed suggesting a significant time underemployment. Additionally, there is a significant proportion of the youth that are skill underemployed; their educational attainment was higher than the educational level required by their current main jobs. Youth unemployment problem is more of an urban phenomenon with a higher proportion of the youth unemployed in Kampala compared to other regions. Our findings suggest increasing labor productivity in agricultural as well as in the non-agricultural informal sector where the majority of the youth are located might help to solve the youth unemployment and underemployment predicaments. There is also need to ensure access to cheap finance by the youth, practical education, secure premises for informal businesses, and design policies to slow down the current population growth rates.

\section{Acknowledgements}

The author would like to acknowledge IDRC for sponsoring a regional project in East Africa, out of which, this paper emerged as a second Ugandan output. 


\section{References}

Louise, F., \& Melissa, S. G. (2008). Working Out of Poverty: Job Creation and the Quality of Growth in Africa. A World Bank Publication.

MFPED. (2007). Background to the Budget 2007/08 Fiscal Year: Re-orienting Government Expenditure towards Prosperity for All. Ministry of Finance, Planning and Economic Development, Kampala.

MFPED. (2012). Priorities for Renewed Economic Growth and Development. Background to the Budget 2012/13. Ministry of Finance, Planning and Economic Development, Kampala.

Ministry of Education and Sports. (2011). Business, Technical and Vocational Education and Tranining Strategic Plan. Technical Report 1 Labour Market.

Ministry of Finance. (2005). Background to the Budget 2005/6: Increasing Investment, Employment, Productivity and Household Incomes through Public Expenditures Ministry of Finance, Planning and Economic Development, Kampala.

Ministry of Finance. (2006). Background to the Budget 2006/7: Enhancing Economic Growth and Household Incomes through Increased Production and Productivity. Ministry of Finance, Planning and Economic Development, Kampala.

Ragui, A., \& Levison. (2013). Employment for Youth. A growing Challenge for the Global Economy. Background Research Paper Submitted to the High Level Panel on the Post-2015 Development Agenda.

Statistical Abstract. (2012). Uganda Bureau of Statistics, Kampala.

The Youth Employment Crisis: A Time for Action. (2012). ILO, Geneva, Switzerland.

UBoS. (2001). Uganda National Household Survey 1999-2000. Entebbe. Uganda Investment Authority (2007) Committed Investments in Agriculture.

UBoS. (2003). Uganda National Household Survey 2002-2003: Social Economic Report. Entebbe.

UBoS. (2007). Uganda National Household Survey 2005-2006: Social Economic Report. Kampala.

UBoS. (2011). Uganda National Household Survey 2009-2010: Social Economic Report. Kampala.

World Bank. (2012). African Development Indicators 2012: Jobs. Washington D.C.: World Bank.

\section{Copyrights}

Copyright for this article is retained by the author(s), with first publication rights granted to the journal.

This is an open-access article distributed under the terms and conditions of the Creative Commons Attribution license (http://creativecommons.org/licenses/by/3.0/). 